\title{
The Spatial and Temporal Distributions of Absorbing Aerosols over East Asia
}

\author{
Litai Kang ${ }^{1}{ }^{(\mathbb{D})}$, Siyu Chen ${ }^{1, *}$, Jianping Huang ${ }^{1}$, Shuman Zhao ${ }^{2}$, Xiaojun Ma ${ }^{1}$, Tiangang Yuan ${ }^{1}$, \\ Xiaorui Zhang ${ }^{1}$ and Tingting Xie ${ }^{1}$ \\ 1 Key Laboratory for Semi-Arid Climate Change of the Ministry of Education, College of \\ Atmospheric Sciences, Lanzhou University, Lanzhou 730000, China; kanglt14@lzu.edu.cn (L.K.); \\ hjp@lzu.edu.cn (J.H.); mxj19900913@163.com (X.M.); yuantg14@lzu.edu.cn (T.Y.); 503218584@qq.com (X.Z.); \\ xiett14@lzu.edu.cn (T.X.) \\ 2 State Key Laboratory of Atmospheric Boundary Layer Physics and Atmospheric Chemistry, Institute of \\ Atmospheric Physics, Chinese Academy of Sciences, Beijing 100029, China; shumanatmos@163.com \\ * Correspondence: chensiyu@lzu.edu.cn; Tel.: +0931-8914139
}

Received: 23 August 2017; Accepted: 12 October 2017; Published: 16 October 2017

\begin{abstract}
Absorbing aerosols can strongly absorb solar radiation and have a profound impact on the global and regional climate. Black carbon (BC), organic carbon (OC) and dust are three major types of absorbing aerosols. In order to deepen the overall understanding of absorbing aerosols over East Asia and provide a basis for further investigation of its role in enhanced warming in drylands, the spatial-temporal distribution of absorbing aerosols over East Asia for the period of 2005-2016 was investigated based on the Ozone Monitoring Instrument (OMI) satellite retrievals. Overall, high values of Aerosol Absorption Optical Depth (AAOD) mainly distribute near dust sources as well as BC and OC sources. AAOD reaches its maximum during spring over East Asia as a result of dust activity and biomass burning. Single-scattering albedo (SSA) is comparatively high $(>0.96)$ in the most part of East Asia in the summer, indicating the dominance of aerosol scattering. Hyper-arid regions have the highest Aerosol Optical Depth (AOD) and AAOD among the five climatic regions, with springtime values up to 0.72 and 0.04 , respectively. Humid and sub-humid regions have relatively high AOD and AAOD during the spring and winter and the highest SSA during the summer. AAOD in some areas shows significant upward trends, which is likely due to the increase of BC and OC emission. SSA shows overall downward trends, indicating the enhancement of the aerosol absorption. Analysis of emission inventory and dust index data shows that $\mathrm{BC}$ and $\mathrm{OC}$ emissions mainly come from the humid regions, while dust sources mainly distribute in drylands.
\end{abstract}

Keywords: absorbing aerosol; Ozone Monitoring Instrument (OMI); Aerosol Absorption Optical Depth (AAOD); black carbon; dust

\section{Introduction}

Absorbing aerosols mainly include black carbon (BC), organic carbon (OC) and dust [1]. BC and OC mainly result from incomplete combustion of fossil fuels and biomass burning [2-6]. Dust primarily comes from natural sources through wind erosion [7-10], and sometimes from anthropogenic sources via modifying landscape or disturbing soil [11,12]. Absorbing aerosols can heat the atmosphere through the absorption of solar radiation [12-17] as well as outgoing long-wave radiation [18-20], which can further lead to changes in atmospheric stability [21,22], clouds and precipitation [23-27], snow and ice [28-30]. Meanwhile, it can cause the changes in near surface temperature as a result of the reduction in surface solar radiation [31-37]. Due to its important role in the climate system, a lot of research has been done focusing on the emission, distribution, transport and climate effect 
of absorbing aerosols on the global scale [38-40] as well as regional scale, including Europe [41,42], North America [43,44], East Asia [45,46], tropics [47,48] and Polar regions [49,50].

Recent studies show that the warming in drylands are $20-40 \%$ higher than that in humid lands over the past century at the global scale [51-54], with similar phenomenon also occurring in East Asia [55]. For instance, Ran et al. [56] found that annual warming rate in drylands of China is 1.7 times greater than that in humid and sub-humid regions of China from 1956 to 2011. Besides the historical observations, enhanced drylands warming is expected to continue in the 21st century, with $44 \%$ more warming projected over global drylands than over humid lands under $2{ }^{\circ} \mathrm{C}$ global warming target [53]. There has been great interest among researchers to investigate the physical mechanisms behind this phenomenon. In previous studies, various factors have been identified to explain the enhanced drylands warming, including atmospheric circulation, snow albedo feedback, surface and atmospheric processes, clouds and human activities [51,53,57-59]. Radiatively forced temperature changes made a major contribution to the enhanced warming in drylands over East Asia and aerosol is one of the radiative factors [53,55]. A recent study shows that enhanced drylands warming over East Asia was strengthened by the warming effect of BC [60]. This study also suggested that temperature in drylands is more sensitive to BC emission than that in humid regions. Additionally, absorbing aerosols over East Asia could also influence Asian monsoon water cycle [46,61], which could affect one fifth of world's population living in this region. East Asia is not only the largest source of anthropogenic BC in the world [44], but also one of the major dust sources $[10,62]$. Therefore, the study of absorbing aerosols over East Asia is of great significance in order to deepen the overall understanding of absorbing aerosols over East Asia as well as the role of absorbing aerosols in enhanced warming in drylands.

Satellite remote sensing is an important tool for the study of spatial-temporal distributions of absorbing aerosols with global coverage and reasonable spatial resolution. In recent years, Ozone Monitoring Instrument (OMI) aerosol products have been widely used in the study of absorbing aerosols [43,63-65]. In comparison with the Moderate Resolution Imaging Spectroradiometer (MODIS) and Multi-angle Imaging Spectroradiometer (MISR) aerosol products, OMI also provides Aerosol Absorption Optical Depth (AAOD) retrievals in addition to widely used Aerosol Optical Depth (AOD). AAOD represents the light attenuation due to the absorption of the aerosols, which is a useful parameter to study the spatial-temporal distribution of absorbing aerosol. OMI AAOD retrieved with OMI nearultraviolet (OMAERUV) algorithm was made in the near-ultraviolet (UV) spectral range. One of the major advantages of measurements in this spectral range is that small surface albedo of snow-free land in UV enable the retrieval of aerosol properties over various land surfaces, including arid and semi-arid regions which tend to be bright in visible band [66]. Another advantage of near-UV observation is that the strong interaction between molecular scattering and aerosol absorption in this spectral range enable the estimation of the absorption capacity of aerosols [67]. OMI retrievals have been widely validated by comparing with observations from the Aerosol Robotic Network (AERONET). Using data during 2005-2008, Ahn et al. [68] compared OMI AOD retrieved using OMAERUV algorithm with AERONET AOD and yielded a satisfactory level of agreement, with correlation coefficient about 0.81 and root-mean-square error (RMSE) about 0.16 . It is also found that the accuracies of OMI, MODIS deep-blue and MISR AOD are statistically comparable in arid and semiarid regions. Zhang et al. [69] evaluated OMI AOD with AERONET AOD retrieved in 27 stations over Central and East Asia, and found that the correlation coefficient is 0.77 , with more accurate retrievals in eastern and northern China and South Korea. As for SSA, OMAERUV retrievals agree quite well with AERONET retrievals, with RMSE smaller than 0.03 [66]. Jethva et al. [70] compared OMI SSA with SSA retrieved based on 269 AERONET stations at global scale and found that approximately $69 \%$ retrievals agree within the absolute difference of \pm 0.05 . Overall, OMI OMAERUV products are reliable and applicable over East Asia.

In this study, the spatial-temporal distribution of absorbing aerosols during 2005-2016 was investigated using satellite retrievals. In addition, the difference of distribution and emission of 
absorbing aerosols in different climatic regions over East Asia are compared and discussed. The paper is organized as follows. Section 2 describes the datasets and methods used in this study and Section 3 provides the results and discussion. Conclusions are given in Section 4.

\section{Data and Methods}

OMI on board Aura satellite is a nadir-viewing spectrometer that can observe solar backscatter radiation in the visible and UV spectrum [71]. There are two types of aerosol algorithms used in the OMI observations: OMI multi wavelength (OMAERO) algorithm and OMAERUV algorithm. OMAERO products are obtained using multi-wavelength information, while OMAERUV products are obtained using observation in two near-UV channels. In this study, OMAERUV Level 3 products including daily mean AOD, AAOD and SSA at $500 \mathrm{~nm}$ during 2005-2016 are used with spatial resolution $1^{\circ} \times 1^{\circ}$. The relationship of AAOD, AOD and SSA can be expressed by AAOD $=(1-\mathrm{SSA}) \times$ AOD [72] Due to the high sensitivity of OMI at near-UV spectrum, AAOD is the most reliable quantitative aerosol parameter in the OMAERUV products, with root-mean-square error estimated to be about 0.01 [73].

BC and OC emission inventory were obtained from The Emissions Database for Global Atmospheric Research (EDGAR) V3.4.1 [74]. EDGAR provides $0.1^{\circ} \times 0.1^{\circ}$ global emissions inventory for different types of gaseous and particulate air pollutants during 1970-2010 (http:/ / edgar.jrc.ec. europa.eu/overview.php? v=431). Additionally, coal and diesel consumption as well as $\mathrm{SO}_{2}$ emission data during 2005-2015 in China are also used in this study, provided by National Bureau of Statistics of China (http:/ / data.stats.gov.cn/index.htm).

Dust events observation data were obtained from the National Meteorological Center of the China Meteorological Administration. This dataset contains monthly record of dust storm, blowing dust and floating dust across China. To ensure the integrity of data at each station, only stations with complete records are used in the analysis. Based on this data, dust index for China during 1970-2010 is further calculated. The details of the method used for the calculation are described in Wang et al. [75], Kang et al. [76] and Yuan et al. [77].

In order to compare the spatial-temporal characteristic of absorbing aerosols in the different climatic regions, this study use aridity index to further divide the study area (Figure 1). Aridity index (AI), which can be defined as the ratio between annual mean precipitation and potential evapotranspiration (PET), is one of the most commonly used indexes in climate classification [78-80]. In this study, AI dataset was provided by Feng and Fu [81], which is derived using the Penman-Monteith method. As showed in Figure 1a, East Asia was divided into five climatic regions: hyper-arid $(\mathrm{AI} \leq 0.05)$, arid $(0.05<\mathrm{AI} \leq 0.2)$, semi-arid $(0.2<\mathrm{AI} \leq 0.5)$, sub-humid $(0.5<\mathrm{AI} \leq 0.65)$ and humid $(\mathrm{AI}>0.65)$ regions. According to the definition given by U.N. Environment Program, areas where AI less than 0.65 can be defined as drylands [82].

For comparison, climate classification based on precipitation (PRE) was also provided in Figure $1 \mathrm{~b}$. Due to its simplicity and convenience, precipitation is also widely used in climate classification [51,55]. National Oceanic and Atmospheric Administration's Precipitation Reconstruction over Land (PREC/L) dataset [83] was used in this study. As showed in Figure 1b, East Asia can be divided into hyper-arid (PRE $\leq 50 \mathrm{~mm})$, arid (50 $\mathrm{mm}<\mathrm{PRE} \leq 200 \mathrm{~mm})$, semi-arid (200 $\mathrm{mm}<\mathrm{PRE} \leq 400 \mathrm{~mm})$, sub-humid (400 $\mathrm{mm}<$ PRE $\leq 600 \mathrm{~mm}$ ) and humid (PRE $>600 \mathrm{~mm}$ ) regions.

It is clear that the area of drylands classified according to $\mathrm{AI}$ (where $\mathrm{AI} \leq 0.65$ ) is smaller than the area of drylands classified according to PRE (where PRE $\leq 600 \mathrm{~mm}$ ). The main difference can be found in the semi-arid and sub-humid regions, especially in high latitudes. Figure 1c provides the annual mean Normalized Difference Vegetation Index (NDVI) during 1982-2008 from the Advanced Very High Resolution Radiometer (AVHRR). Vegetation is quite sensitive to aridity. It can be seen that the spatial pattern of NDVI matches up better with AI than with precipitation. This is because the aridity is affected by many factors including precipitation, temperature and evaporation $[79,80]$. The classification approach based on AI also takes into account the importance of temperature and 
evaporation, while another approach is solely based on precipitation. Therefore, we use AI to classify climatic regions in this study.
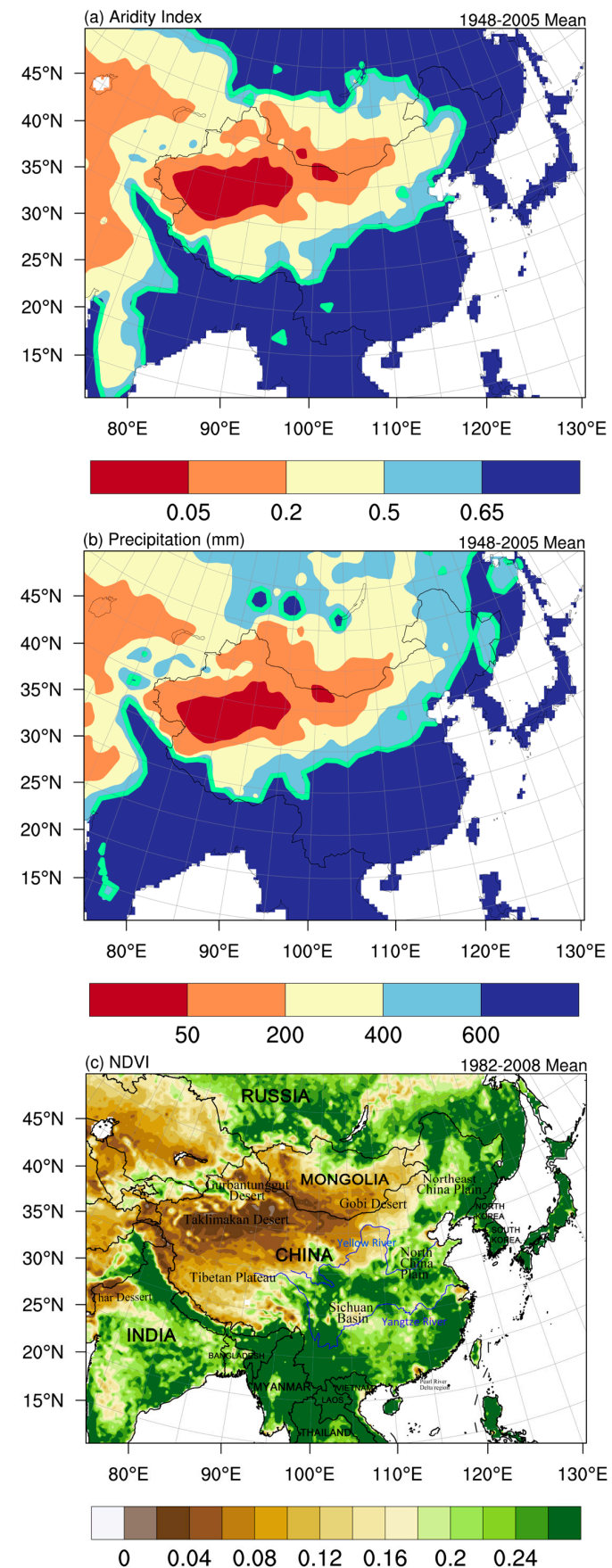

Figure 1. Annual means of (a) Aridity Index and (b) precipitation (mm) during 1948-2005 and (c) NDVI from AVHRR during 1982-2008 over East Asia. The green line in $(\mathbf{a}, \mathbf{b})$ is the boundary line between drylands and humid lands.

The linear trends of variables (e.g., AOD) were calculated using simple linear regression. Given a sample of $n$ data pairs $x\left(x_{i}, i=1, \ldots, n\right)$ and $y\left(y_{i}, i=1, \ldots, n\right)$, we assume that their relationship can be represented by

$$
y_{i}=a+b x_{i}
$$


In our application, $x$ represents the time and $y$ represents the time series of different variables. The parameters $a$ and $b$ can be estimated with least-squares approach.

$$
\left\{\begin{array}{l}
b=\frac{\sum_{i-1}^{n}\left[\left(x_{i}-\bar{x}\right)\left(y_{i}-\bar{y}\right)\right]}{\sum_{i-1}^{n}\left(x_{i}-\bar{x}\right)^{2}} \\
a=\bar{y}-b \bar{x}
\end{array}\right.
$$

where $\bar{x}$ and $\bar{y}$ is the average of the $x_{i}$ and $y_{i}$ and regression coefficient $b$ is the linear trend.

\section{Results and Discussion}

AOD is one of the most commonly used aerosol parameter, which describes the total extinction (both scattering and absorption) of aerosol. In recent years, the spatial-temporal distribution of AOD over East Asia has been studied mainly using satellite retrievals, such as MODIS and MISR, as well as ground-based observation from AERONET [84-89] Compared to other satellite products, the advantage of AOD retrieved from OMI is that observation at the near-UV band is sensitive to not only the scattering but also absorption of aerosols, which enable OMI to further retrieve SSA and AAOD. Figure 2 shows the seasonal mean AOD retrieved from OMI East Asia from 2005 to 2016. Overall, a high AOD area can be found in the Taklimakan desert throughout the year. In the spring (March, April and May, MAM), AOD in the Taklimakan desert is greater than 0.7. High AOD values can also be found in Southeast Asia (about 0.5-0.7). In autumn (September, October and November, $\mathrm{SON}$ ), AOD in the most parts of the humid lands decrease below 0.3. In winter (December, January and February, DJF), AOD is about 0.3 in Sichuan Basin, the North China Plain and the middle and lower reaches of the Yangtze River, which is slightly smaller than the AOD in the Taklimakan desert ranging from 0.4 to 0.5 .

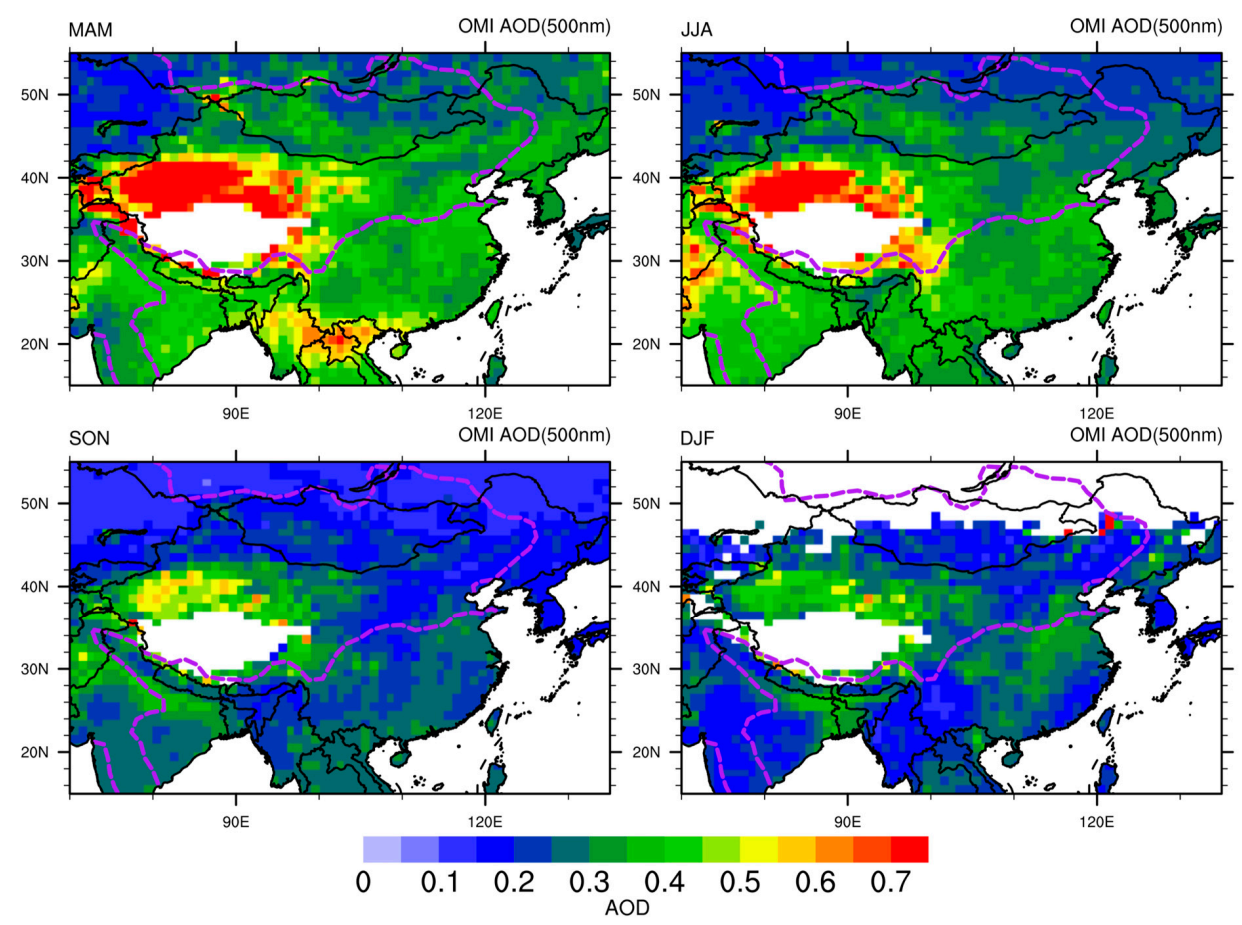

Figure 2. The seasonal mean AOD at $500 \mathrm{~nm}$ retrieved from OMI in East Asia from 2005 to 2016. The Purple dotted line is the boundary line between drylands and humid lands (aridity index equals 0.65).

AAOD can be defined as the atmospheric column integral of spectral aerosol absorption coefficient, which is a key parameter to assess the aerosol atmospheric heating [90]. Hu et al. [91] found that 
AAOD over East Asia are mainly contributed by BC and dust, while other aerosols only contribute a small amount towards AAOD. Based on the measurements from the East Asian Study of Tropospheric Aerosols campaign (EAST-AIRE), Yang et al. [92] estimated the mass absorption efficiency (MAE, also known as mass absorption cross section) of BC, OC and dust at $550 \mathrm{~nm}$ to be $9.5,0.5$ and $0.03 \mathrm{~m}^{2} \cdot \mathrm{g}^{-1}$, respectively. It has also been found that $\mathrm{BC}$ contributed most to the total absorption, while the contribution of OC and dust became significant at shorter wavelengths or during the dust events [92]. The seasonal mean AAOD over East Asia from the OMI retrievals averaged for 2005-2016 is shown in Figure 3. In general, AAOD is the highest in spring and lowest in summer (June, July and August, JJA) over East Asia. Large seasonal variation of AAOD can be seen in most areas except the Taklimakan desert. Especially, in the spring, drylands are characterized by high AAOD (greater than 0.03), which can be attributed to the frequent dust activity [74,93]. The monthly mean AAOD (Figure 4) shows that the AAOD deceases from March to May as a result of the weakening of dust activity $[15,94]$. In humid regions, high AAOD values (greater than 0.045) can be found in Myanmar, Laos, Vietnam and northern Thailand, which is related to the large-scale biomass burning activity in Southeast Asia [95]. According to the monthly mean AAOD map (Figure 4), AAOD in these areas peaks in March, which is similar to the results provided by Duncan et al. [96] using Total Ozone Mapping Spectrometer (TOMS) aerosol index data. Recent studies show that biomass burning in Southeast Asia can further influence Southwest China, Pearl River Delta Region though long-range transport [97]. As showed in Figure 2, AAOD in Southwest China and Pearl River Delta Region are also greater than 0.036. Back trajectory analyses also suggested the BC from Southeast Asia can influence the BC concentration over Himalayan region [98].

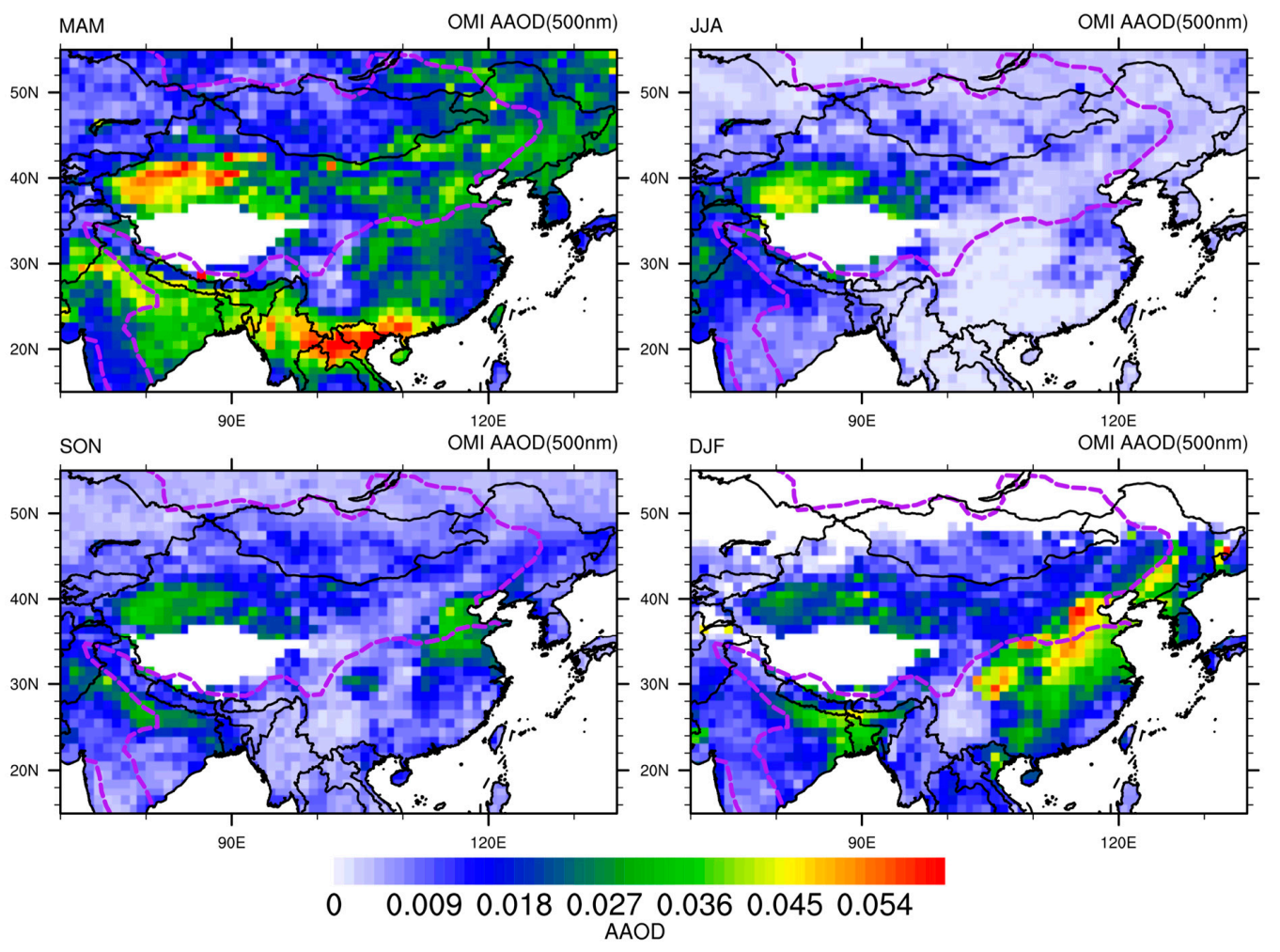

Figure 3. The seasonal mean AAOD at $500 \mathrm{~nm}$ retrieved from OMI in East Asia from 2005 to 2016. The Purple dotted line is the boundary line between drylands and humid lands (aridity index equals 0.65).

High AAOD values are mainly found in the Taklimakan desert and Thar Desert in summer. Due to the limited intensity and scale of summer dust event, the influence of dust aerosol is mainly restricted to the dust sources. For most humid areas, AAOD is smaller than 0.015 and reach the bottom 
in July (Figure 4), lower than 0.004. Overall, AAOD in summer over East Asia is smaller than that in other seasons, indicating a low concentration of absorbing aerosol in summer, which is consistent to the previous observation and simulation results. Cao et al. [99] analyzed the BC and OC concentrations in 17 cities (mostly in humid region) over China during 2003 and found that these two types of absorbing aerosols are lowest in summer, with concentrations accounts for only one third of the concentrations in winter. Model simulation results also show that BC and OC reach the minimum in summer, with lowest values in July [100,101]. In the summer, AOD in humid lands was about 0.4 (Figure 2), while the corresponding AAOD was less than 0.015 , indicating strong aerosol scattering.

AAOD starts to increase in autumn, especially in humid lands. AAOD in North China Plain and Northeast India is greater than 0.027. Monthly mean AAOD (Figure 4) shows that there is a rise in AAOD over humid lands in East Asia from September to November. Previous study also shows that BC and OC emission also show an upward trend since September [101]. Most of the BC and OC emission can be attributed to the humid regions according to the inventory data [102], which explains why the increase in AAOD is more evident here.

In winter, high AAOD values mainly distribute in the humid lands. AAOD in North China Plain, Sichuan Basin and Northeast China Plain is greater than 0.045, which even exceeds AAOD in the Taklimakan desert. BC and OC concentration increased evidently as winter heating period begins. According to the Asian emission inventory in 2006 developed for the NASA INTEX-B mission [103], $\mathrm{BC}$ and $\mathrm{OC}$ emission reach maximum in winter.

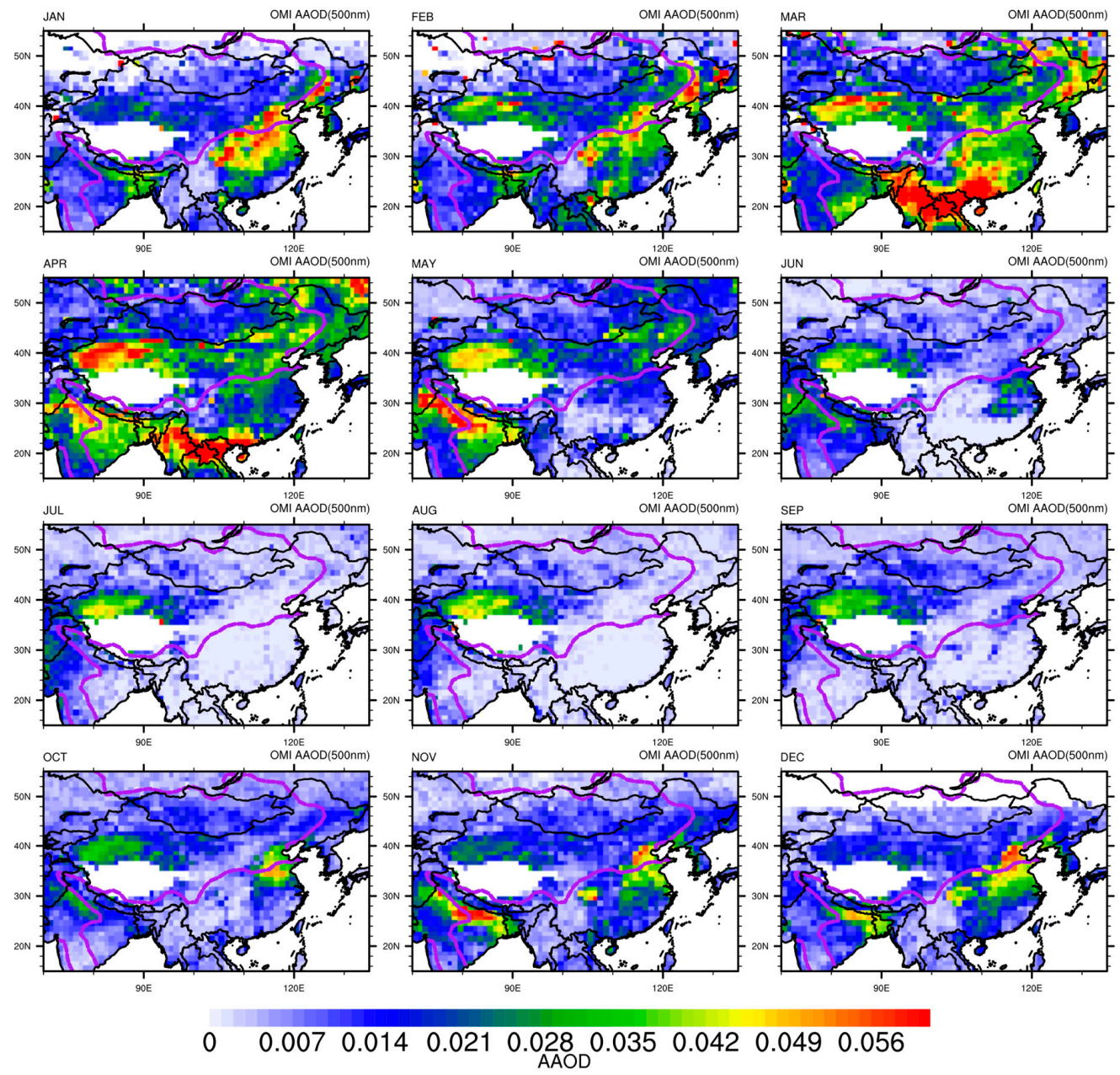

Figure 4. The monthly mean AAOD at $500 \mathrm{~nm}$ retrieved from OMI in East Asia from 2005 to 2016. The Purple dotted line is the boundary line between drylands and humid lands (aridity index equals 0.65). 
SSA is defined as the ratio of scattering coefficient to extinction coefficient (the sum of scattering coefficient and absorption coefficient) [104], with theoretical values ranging from 0 (completely absorbing) to 1 (completely scattering). Normally, SSA is between from 0.5 to 1.0 in the visible and UV spectrum [105]. SSA is the key parameter that controls the aerosol climate effect; the variation of SSA value can lead to a change in aerosol radiative forcing [106,107]. Figure 5 shows the seasonal mean SSA over East Asia from the OMI retrievals averaged for 2005-2016.

In the spring, low SSA values mainly can be seen in dust source regions, including the Taklimakan desert, Gobi desert and Kerqin sandy land in China as well as Thar dessert in India, with SSA lower than 0.96. In Southeast Asia and Northeast India, where frequent biomass burning occur, also have relatively low SSA value about 0.90 0.96.

The spatial pattern of SSA in summer is distinctive among the four seasons. Except for the low SSA in dust source regions (about 0.94-0.97), SSA values in most areas are greater than 0.98 , which indicates strong aerosol scattering. It is likely that high SSA value are related to the abundant water vapor in summer, which will further lead to high relative humidity, and aerosol scatter efficiency would be enhanced through moisture hygroscopic growth [84]. Previous study found there is a positive relationship between SSA and relative humidity [108].

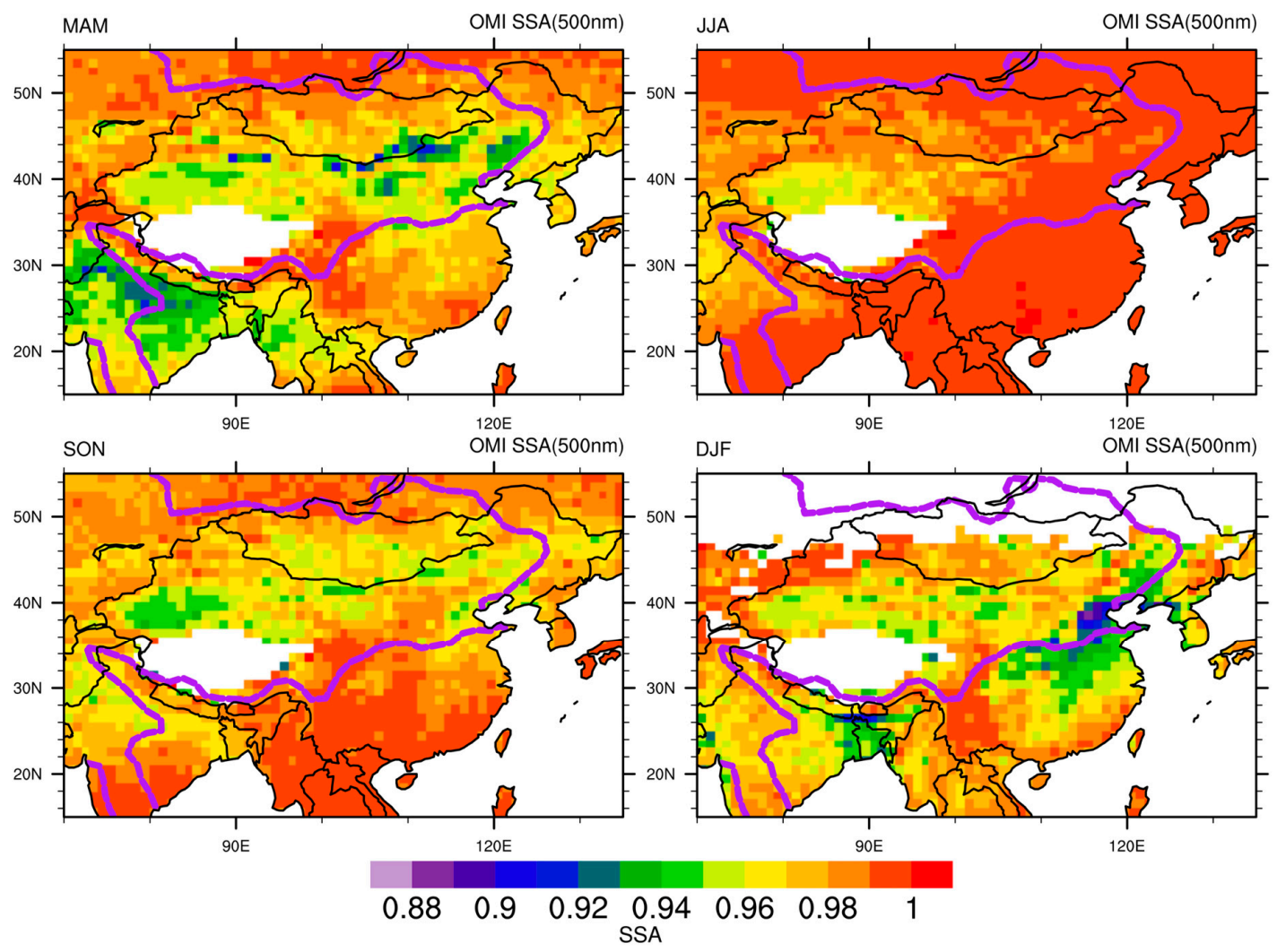

Figure 5. The seasonal mean SSA at $500 \mathrm{~nm}$ retrieved from OMI in East Asia from 2005 to 2016. The Purple dotted line is the boundary line between drylands and humid lands (aridity index equals 0.65).

The distribution of low SSA values in autumn was similar to that in spring, which mainly distributed in drylands. The SSA is about 0.94 in the Taklimakan desert and Gobi Desert. In winter, the low SSA value mainly distributed in humid lands, including the North China Plain, the Northeast Plain, the middle and lower reaches of the Yangtze River, the Sichuan Basin in China and Bangladesh, which is about 0.90-0.96. The monthly mean SSA (Figure 6) shows that the area with low SSA value in the humid lands is the largest in January. SSA in the humid land starts to rise up again from February. 


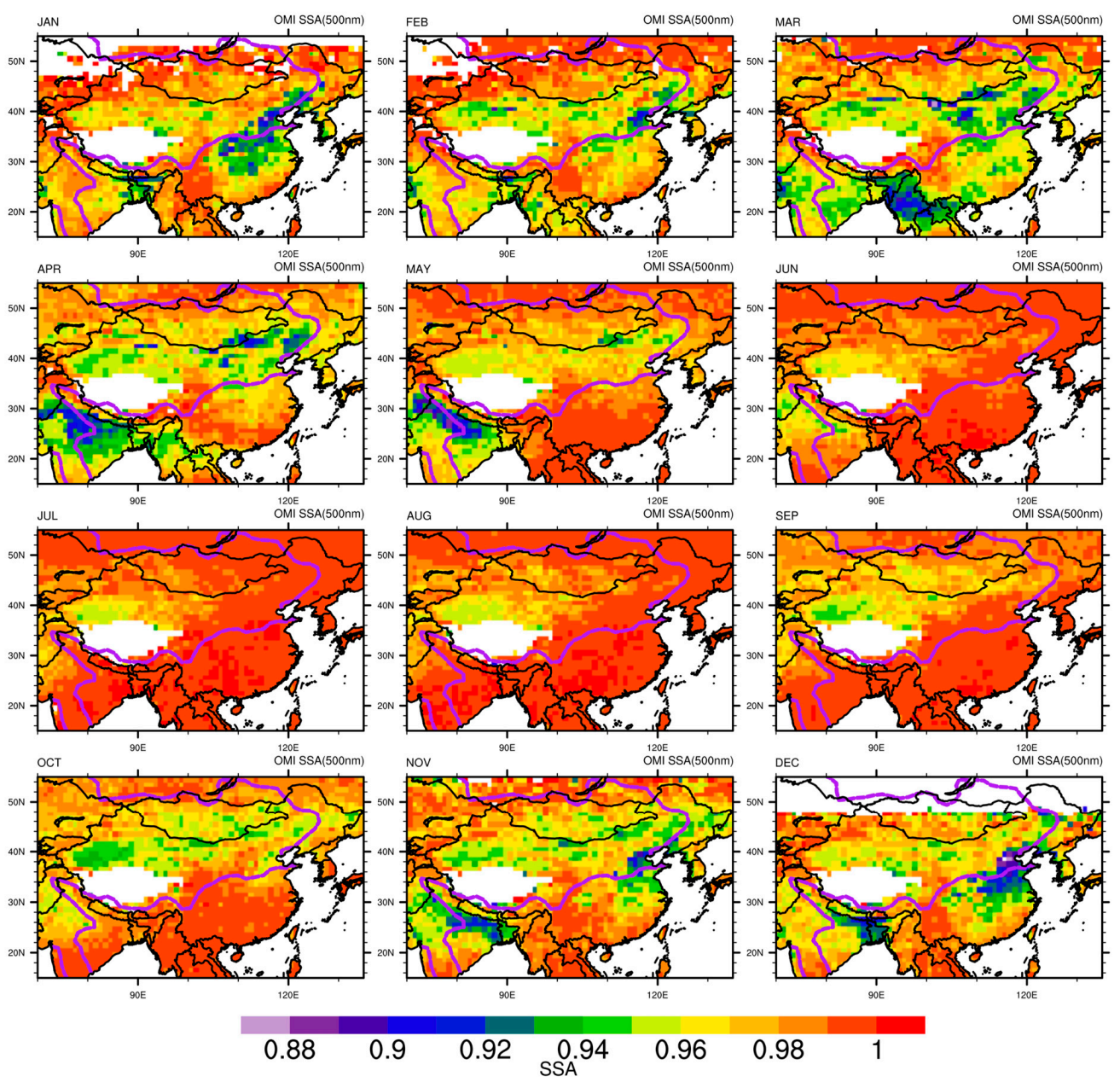

Figure 6. The monthly mean SSA at $500 \mathrm{~nm}$ retrieved from OMI in East Asia from 2005 to 2016. The Purple dotted line is the boundary line between drylands and humid lands (aridity index equals 0.65).

Based on previous analysis, it is clear that absorbing aerosol over East Asia shows different seasonal characteristics in drylands and humid lands. To further understand the spatial distribution of absorbing aerosol over different climatic regions, Figure 7 provides the seasonal mean of AAOD, SSA and AOD over five climatic regions.

AAOD and AOD of hyper-arid regions is the highest among the five regions throughout the year, especially in spring, when AAOD and AOD reach up to 0.04 and 0.72 , respectively. Despite of the seasonal variation of intensity for dust activity, there is always a large dust loading over dust sources located in hyper-arid regions. Due to the existence of dust, SSA of hyper-arid regions is the lowest among the five regions, about 0.96 in spring and autumn. Arid regions are also strongly influenced by dust aerosols, with AOD and AAOD values surpassed only by hyper-arid region in the spring, summer and autumn. The influence of dust on the semi-arid regions is relatively smaller. AAOD and AOD over semi-arid regions is the lowest among the five regions, except in summer. During spring and winter, AAOD and AOD in humid and sub-humid regions are greater than those in arid and semi-arid regions. It is likely due to the enhanced BC and OC emissions in humid and sub-humid regions during this period. In winter, SSA value in humid and sub-humid regions is comparable to that of hyper-arid regions, indicating the strong aerosol absorption. In contrast, aerosol scattering is dominant over humid and sub-humid regions in summer. Analysis of the radiative effective of absorbing aerosols in the different climatic regions of East Asia is also necessary to investigate the role 
of absorbing aerosols in enhanced warming in drylands, which will be presented in a follow-up paper based on simulation results.
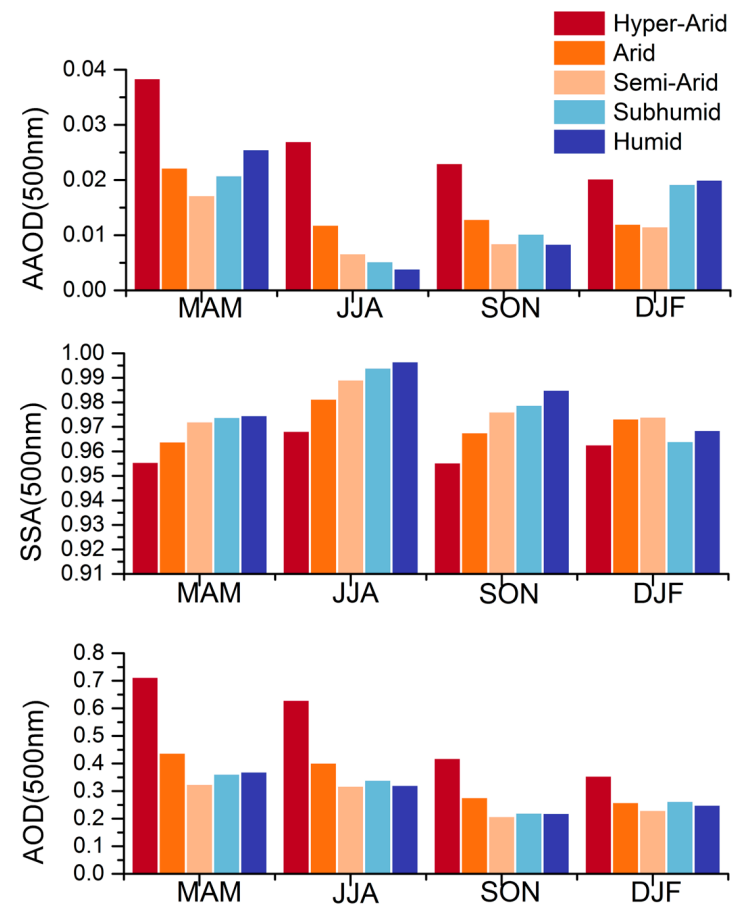

Figure 7. The seasonal mean AAOD, AOD and SSA at $500 \mathrm{~nm}$ retrieved from OMI over different climate regions in East Asia from 2005 to 2016.

In order to further understand the variation of absorbing aerosols over East Asia, we further calculate the linear trends of AOD (Figure 8), AAOD (Figure 9) and SSA (Figure 10) during 2005-2016.The area masked with grid represents the areas passed the significant test (significance level $\alpha=0.05$ ).

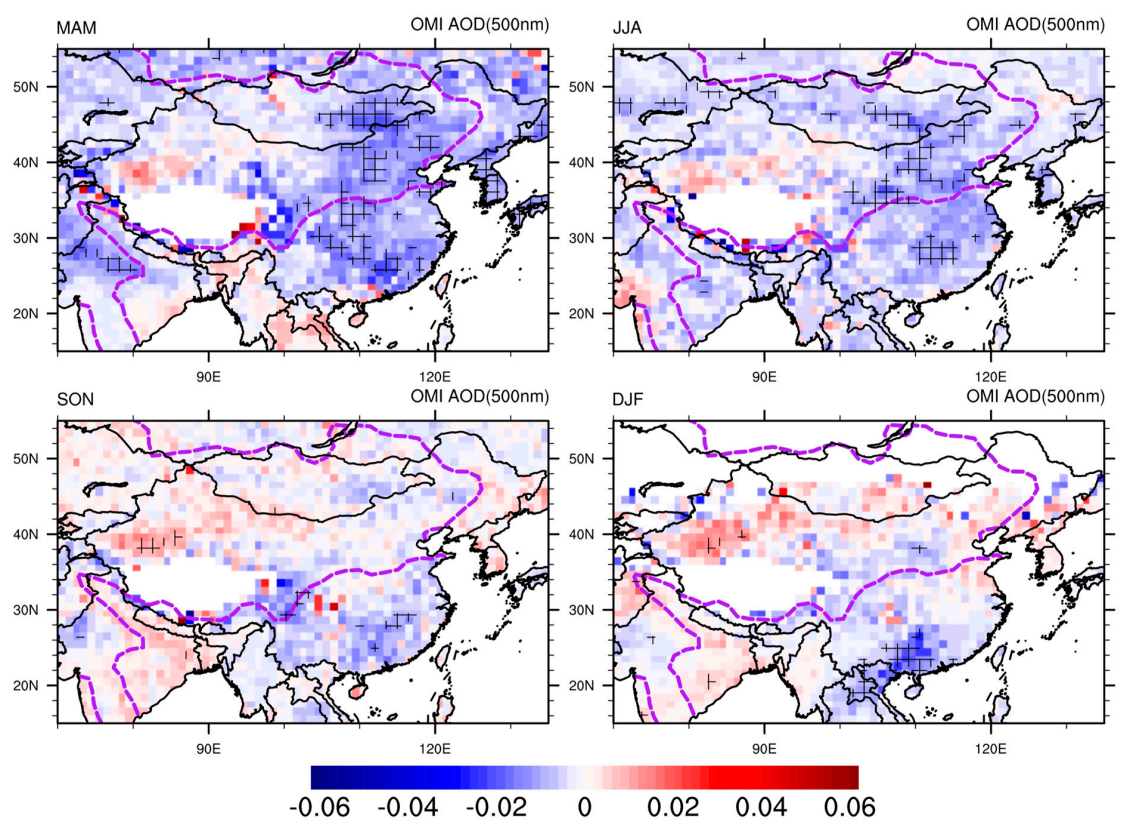

Figure 8. The linear trends of OMI AOD at $500 \mathrm{~nm}$ for 2005-2016. The grid represents the areas with $95 \%$ confidence. 

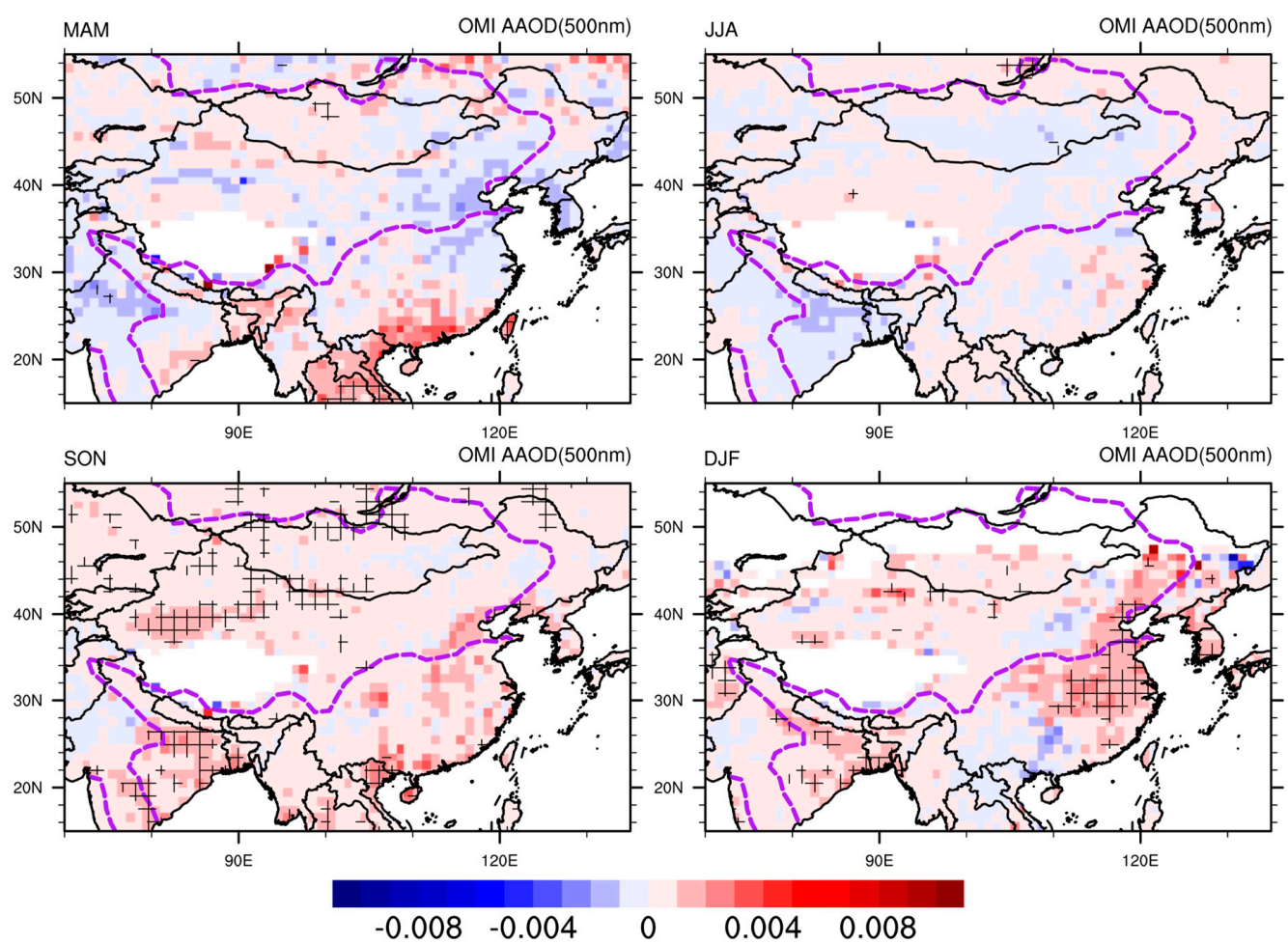

Figure 9. The linear trends of OMI AAOD at $500 \mathrm{~nm}$ for 2005-2016. The grid represents the areas with $95 \%$ confidence.
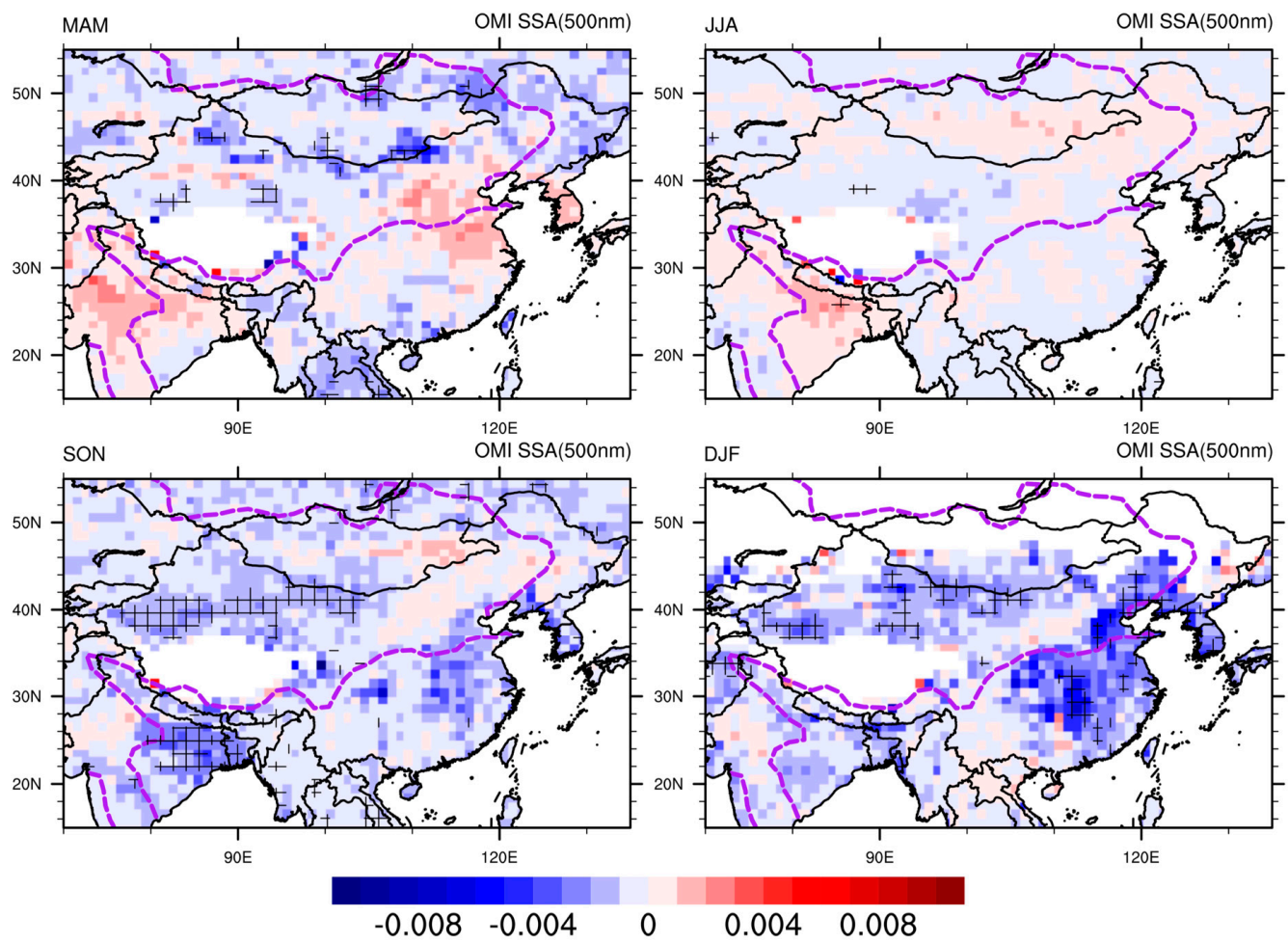

Figure 10. The linear trends of OMI SSA at $500 \mathrm{~nm}$ for 2005-2016. The grid represents the areas with $95 \%$ confidence.

AOD shows downward trends (about -0.001 year $^{-1}$ to -0.003 year $^{-1}$ ) over the large parts of East Asia from 2005 to 2016(Figure 8). The most significant decrease of AOD can be found in the 
Inner Mongolia plateau and southern China in spring and summer and in the Pearl River Delta region in winter. The dominant aerosol types that contribute most to the AOD over East Asia are sulfate and dust [91]. In China, for example, AOD of sulfate and dust accounts for 31 33\% and 28 30\% [109] of the total AOD, respectively. De Meij et al. [110] suggested that AOD trends over East Asia are dominated by sulfur dioxide $\left(\mathrm{SO}_{2}\right)$ emission changes despite of increasing importance of NOx emissions. In the drylands, the decrease of AOD may be related to the decrease of dust activity here. The decrease of AOD in southern China, in the humid lands, may be related to the decrease of sulfate aerosol. Figure 11c shows the time series of $\mathrm{SO}_{2}$ emission in China during 2005-2015. $\mathrm{SO}_{2}$ is widely known as the precursor of the sulfate aerosol. It is found that $\mathrm{SO}_{2}$ emission has declined by 0.68 million tons per year since 2006. Based on a different dataset, Lu et al. [111] also provided a similar result and pointed out that $\mathrm{SO}_{2}$ emission in China has changed from rising to declining in 2006.
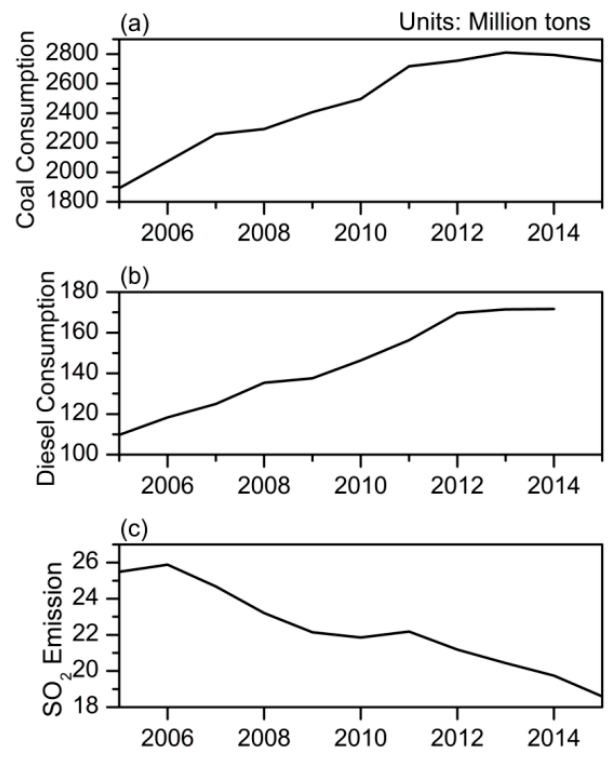

Figure 11. The time series of (a) total coal consumption, (b) total diesel consumption and (c) sulfur dioxide emissions from 2005 to 2015 in China.

In spring, AAOD changes most significantly in Southeast Asia (about 0.003 year $^{-1}$ ) as showed in Figure 9. This may be related to the increase of springtime biomass burning. For summer, no significant change of AAOD has been found. Overall, AAOD shows an upward trend in autumn. The increase of AAOD in the Taklimakan desert suggests that the dust activity during autumn has increased in these years. Meanwhile, the significant increase of AAOD can be found in the Southeast Asia. In winter, AAOD still shows an upward trend on the whole, and the most significant areas (about 0.003 year $^{-1}$ ) are distributed in the North China Plain, the middle and lower reaches of the Yangtze River, the Korean Peninsula and northeast India. The rise of AAOD in these regions is likely due to an increase of $\mathrm{BC}$ and $\mathrm{OC}$ emissions. Take China, for example: the total coal and diesel consumption during 2005-2015 is provided in Figure 11. It is clear that the total coal and diesel consumption both shows an overall upward trend since 2005, increased by 91.51 and 7.42 million tons each year, respectively. Incomplete combustion of fossil fuels such as coal and diesel is an important source of BC and OC [112], thus the increasing trend of them partly explains the increasing trend of AAOD in the humid lands over China in the autumn and winter. Although this study has provided a brief discussion, more detailed and comprehensive study is needed to provide detailed explanations, which is beyond the scope of this study. Similarly, Zhang et al. [43] analyzed the linear trend of AAOD in the United States (U.S.) over 2005-2015 using OMAERUV products and found an obvious upward trend in four seasons. Analysis [43] shows that the increase in AAOD over U.S. can mainly attributed to the increasing concentration of dust rather than BC. In contrast, AAOD in East Asia only 
shows significant upward trend in autumn and winter and is related to both dust and carbonaceous aerosols. Mallet et al. [113] studied 17-year (1996-2012) aerosol absorption properties from AERONET observations over Mediterranean and found a decrease in AAOD over Rome and several other Sites, especially those under the influence of dust.

Figure 10 shows the linear trends SSA over East Asia for 2005-2016. In general, SSA in East Asia shows a downward trend, indicating the increase of aerosol absorption. In the autumn, the most significant decrease of SSA can be found in northwestern China and northeastern India, which is opposite to the trend of AAOD. During the winter, the SSA declines significantly in the middle and lower reaches of the Yangtze River, North China Plain and desert regions, with the trend coefficient less than -0.004 year $^{-1}$.

AAOD, SSA and AOD from the OMI retrievals provide the overall spatial-temporal characteristic of absorbing aerosols over East Asia. It is necessary to further analyze the distribution of $\mathrm{BC}, \mathrm{OC}$ and dust separately. Figure 12 shows the annual mean of $\mathrm{BC}$ and $\mathrm{OC}$ emission over East Asia as well dust Index over China during 1970-2010. BC and OC emission inventories were obtained from EDGAR. Dust index was defined using dust events record from weather stations in China. High BC and OC emissions mainly distribute in humid regions, including the Korean Peninsula, Northeastern India, Bangladesh, Vietnam and parts of China (e.g., Sichuan basin, the North China Plain, the middle and lower reaches of the Yangtze River and the Pearl River Delta region), with BC and OC emission more than $1.35 \times 10^{-11} \mathrm{~kg} \cdot \mathrm{m}^{-2} \cdot \mathrm{s}^{-1}$ and $4.0 \times 10^{-11} \mathrm{~kg} \cdot \mathrm{m}^{-2} \cdot \mathrm{s}^{-1}$, respectively. High dust index values mainly can be found in drylands, with dust index greater than 100 . Dust can be further transported to sub-humid and humid regions, but the influence of dust is limited, with dust index about 1 11. However, it is important to note that dust index used here only represent the natural dust emission. In fact, human activity can also lead to dust emission [11]. Using the dust AOD detected by Cloud-Aerosol Lidar and Infrared Pathfinder Satellite Observations(CALIPSO) and land-use data from MODIS, Huang et al. [12] developed an algorithm to detect anthropogenic dust and found that there is large anthropogenic dust loading over North China Plain.

Because of the limited timespan of OMI dataset, only 11-year trends are analyzed above. In order to investigate the changes of absorbing aerosols over East Asia in a longer time scale, Figure 12 shows the linear trend of BC and OC emission and dust index during 1970-2010. Generally speaking, BC and OC emission show an upward trend over East Asia, especially in humid regions. Areas with most significant increase in BC emission include Shanxi Province and the Pearl River Delta region, with linear trend coefficient greater than $8.4 \times 10^{-13} \mathrm{~kg} \cdot \mathrm{m}^{-2} \cdot \mathrm{s}^{-1} \cdot \mathrm{year}^{-1}$. Areas with most significant increase in OC emission can be found in Northeastern India, southern Myanmar, northern Vietnam, and China's Pearl River Delta region. As for dust activity in China, trend analysis shows an overall downward trend of dust index in China during 1970-2010.
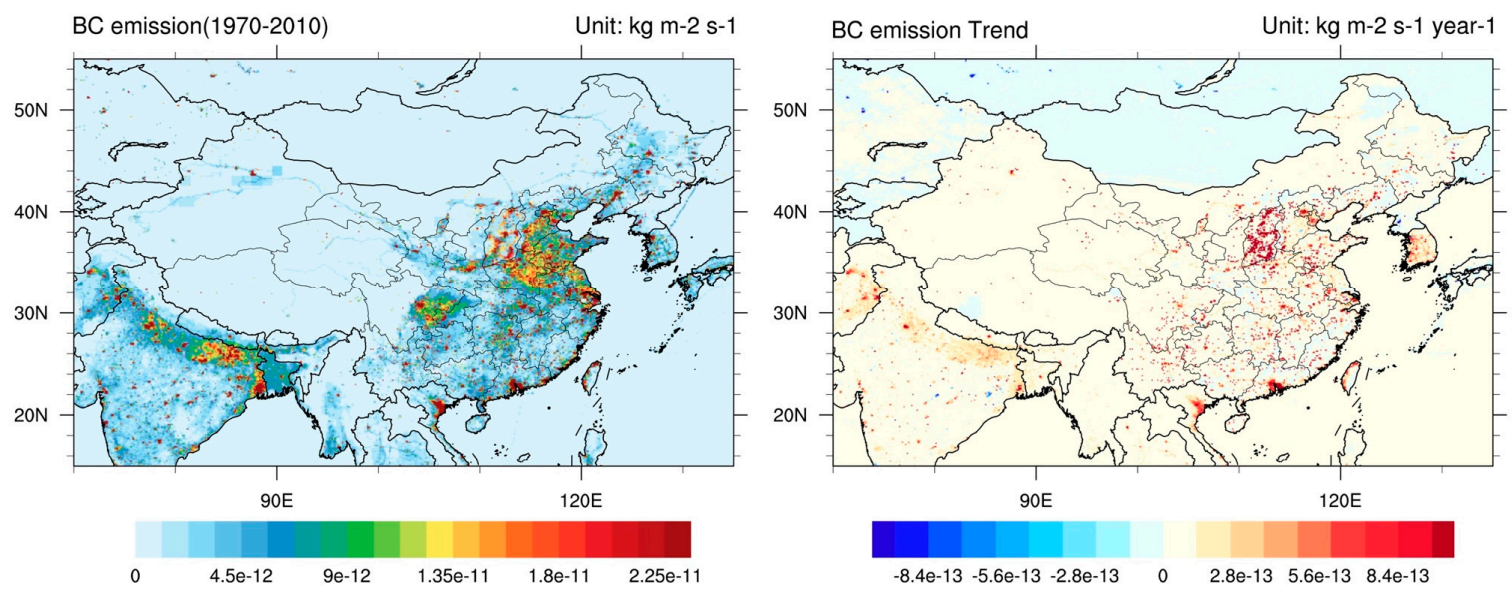

Figure 12. Cont. 

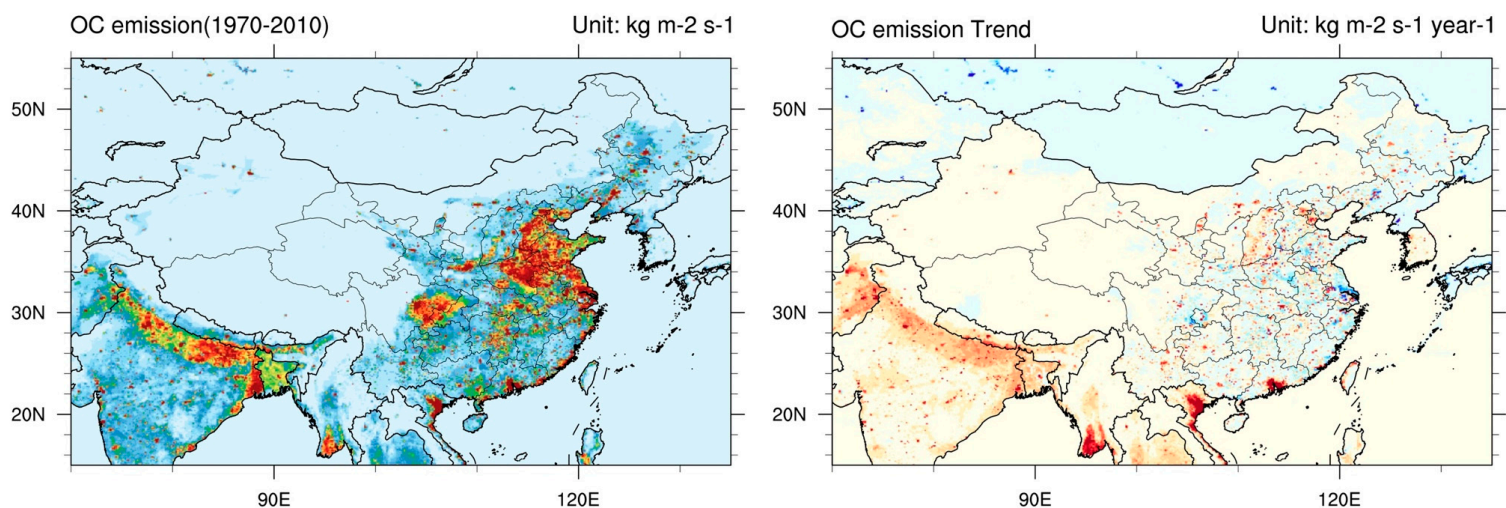

120

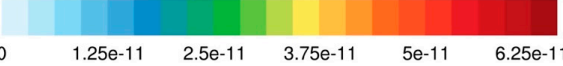

Dust Index(1970-2010)
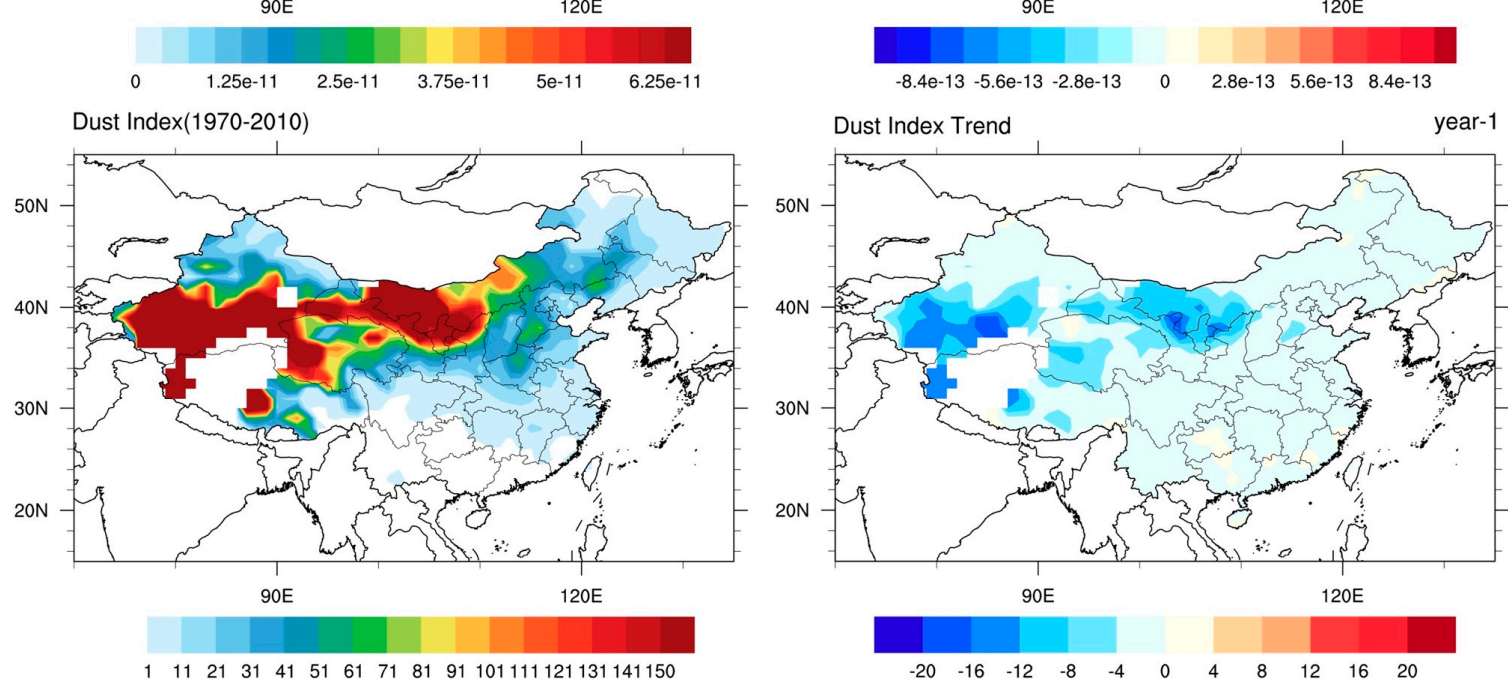

Figure 12. Annual mean and linear trend of $\mathrm{BC}$ and $\mathrm{OC}$ emission and dust index over China during 1970-2010.

\section{Conclusions}

In this study, we studied the spatial-temporal characteristics of absorbing aerosol over East Asia from 2005 to 2016. Overall, high AAOD values mainly distribute near dust sources as well as BC and OC sources. AAOD reaches maximum in the spring over East Asia as a result of dust activity and biomass burning. In winter, the high AAOD values mainly can be found in humid regions. Summertime SSA is comparatively high in the humid regions $(>0.96)$, which means that aerosol scattering is dominant. In contrast, wintertime SSA is generally lower in humid regions compared with drylands. To further understand the spatial distribution of absorbing aerosol over five climatic regions, we compared the seasonal mean AAOD, SSA and AOD averaged over different regions. Hyper-arid regions have highest AOD and AAOD, with springtime values reaching up to 0.72 and 0.04 , respectively. SSA of hyper-arid regions is the lowest among the five regions, about 0.96 in spring and autumn. In contrast, AAOD and AOD over semi-arid regions is the lowest among the five regions, except in summer. Humid and sub-humid regions have relatively high AOD and AAOD during the spring and winter and highest SSA during the summer. Trend analysis shows that AAOD in some areas shows significant upward trends in the period of 2005-2016, which is likely due to the increase of BC and OC emissions. SSA over East Asia shows overall downward trends, indicating the enhancement of the aerosol absorption in recently years. In contrast to AAOD, AOD over East Asia shows downward trends. The decrease of AOD in southern China is presumably related to the reduction of sulfate aerosols.

We also studied the spatial pattern of BC and OC emission as well as dust index during 1970-2010. $\mathrm{BC}$ and $\mathrm{OC}$ emissions mainly distributed in the humid areas, including the Korean Peninsula, Northeastern India, Bangladesh, Vietnam and parts of China. High dust index values mainly distribute 
in drylands. Overall, BC and OC emission has increased over East Asia during 1970-2010, especially in humid lands, while the occurrence of dust events has decreased over China during the same period.

Acknowledgments: This research was supported by the Foundation for National Natural Science Foundation of China (No. 41405003), Innovative Research Groups of the National Science Foundation of China (No. 41521004), the China 111 Project (No. B13045) and Foundation of Key Laboratory for Semi-Arid Climate Change of the Ministry of Education in Lanzhou University (No. lzujbky-2017-kb02). We also want to thank Dr. Yongjie Huang (IAP/CAS) for providing map database (https: / coding.net/u/huangynj/p/NCL-Chinamap/git).

Author Contributions: Litai Kang and Siyu Chen designed the study. Litai Kang carried out the research and wrote the manuscript. Siyu Chen and Jianping Huang contributed to the preparation of the manuscript through review, editing, and comments. Shuman Zhao contributed in the writing of the results section. Xiaojun Ma, Tiangang Yuan, Xiaorui Zhang and Tingting Xie helped polish the manuscript and proposed many useful suggestions to improve its quality. All authors were involved in modifying the paper, the literature review and the discussion of the results.

Conflicts of Interest: The authors declare no conflict of interest.

\section{References}

1. Cazorla, A.; Bahadur, R.; Suski, K.J.; Cahill, J.F.; Chand, D.; Schmid, B.; Ramanathan, V.; Prather, K.A. Relating aerosol absorption due to soot, organic carbon, and dust to emission sources determined from in situ chemical measurements. Atmos. Chem. Phys. 2013, 13, 9337-9350. [CrossRef]

2. Menon, S.; Hansen, J.; Nazarenko, L.; Luo, Y. Climate effects of black carbon aerosols in China and India. Science 2002, 297, 2250-2253. [CrossRef] [PubMed]

3. Heald, C.; Jacob, D.; Turquety, S.; Hudman, R.; Weber, R.; Sullivan, A.; Peltier, R.; Atlas, E.; de Gouw, J.; Warneke, C.; et al. Concentrations and sources of organic carbon aerosols in the free troposphere over North America. J. Geophys. Res. Atmos. 2006, 111, 5573-5588. [CrossRef]

4. Cheng, T.; Han, Z.; Zhang, R.; Du, H.; Jia, X.; Wang, J.; Yao, J. Black carbon in a continental semi-arid area of Northeast China and its possible sources of fire emission. J. Geophys. Res. Atmos. 2010, 115, 23204. [CrossRef]

5. Wang, H.; He, Q.; Kang, Y.; Chen, Y. Characterization of black carbon concentrations of haze with different intensities in Shanghai by a three-year field measurement. Atmos. Environ. 2014, 99, 536-545. [CrossRef]

6. Wang, H.; Kang, Y.; He, Q.; Chen, Y. Transport of black carbon aerosols from non-local sources: A case study in Shanghai. Particulogy 2015, 20, 89-93. [CrossRef]

7. Gillette, D.; Passi, R. Modeling dust emission caused by wind erosion. J. Geophys. Res. Atmos. 1988, 93, 14233-14242. [CrossRef]

8. Huang, J.; Lin, B.; Minnis, P.; Wang, X.; Hu, Y.; Yi, Y.; Ayers, J. Satellite-based assessment of possible dust aerosols semi-direct effect on cloud water path over East Asia. Geophys. Res. Lett. 2006, 33, L19802. [CrossRef]

9. Huang, J.; Minnis, P.; Yi, Y.; Tang, Q.; Wang, X.; Hu, Y.; Liu, Z.; Ayers, K.; Trepte, C.; Winker, D. Summer dust aerosols detected from CALIPSO over the Tibetan Plateau. Geophys. Res. Lett. 2007, 34, L18805. [CrossRef]

10. Huang, J.; Wang, T.; Wang, W.; Li, Z.; Yan, H. Climate effects of dust aerosols over East Asian arid and semi-arid regions. J. Geophys. Res. Atmos. 2014, 19, 11398-11416. [CrossRef]

11. Tegen, I.; Fung, I. Contribution to the atmospheric mineral aerosol load from land surface modification. J. Geophys. Res. Atmos. 1995, 100, 18707-18726. [CrossRef]

12. Huang, J.; Liu, J.; Chen, B.; Nasiri, S. Detection of anthropogenic dust using CALIPSO lidar measurements. Atmos. Chem. Phys. 2015, 15, 11653-11665. [CrossRef]

13. Huang, J.; Minnis, P.; Lin, B.; Wang, T.; Yi, Y.; Hu, Y.; Sun-Mack, S.; Ayers, K. Possible influences of Asian dust aerosols on cloud properties and radiative forcing observed from MODIS and CERES. Geophys. Res. Lett. 2006, 33. [CrossRef]

14. Chen, S.; Huang, J.; Zhao, C.; Qian, Y.; Leung, L.; Yang, B. Modeling the transport and radiative forcing of Taklimakan dust over the Tibetan Plateau: A case study in the summer of 2006. J. Geophys. Res. Atmos. 2013, 118, 797-812. [CrossRef]

15. Chen, S.; Zhao, C.; Qian, Y.; Leung, L.; Huang, J.; Huang, Z.; Bi, J.; Zhang, W.; Shi, J.; Yang, L.; et al. Regional modeling of dust mass balance and radiative forcing over East Asia using WRF-Chem. Aeolian Res. 2014, 15, 15-30. [CrossRef] 
16. Chen, S.; Huang, L.; Kang, H.; Wang, X.; Ma, Y.; He, T.; Yuan, B.; Yang, Z.; Huang, Z.; Zhang, G. Emission, transport and radiative effects of mineral dust from Taklimakan and Gobi Deserts: Comparison of measurements and model results. Atmos. Chem. Phys. 2017, 17, 1-43. [CrossRef]

17. Zhang, H.; Wang, Z.; Guo, P.; Wang, Z. A modeling study of the effects of direct radiative forcing due to carbonaceous aerosol on the climate in East Asia. Adv. Atmos. Sci. 2009, 26, 1-10. [CrossRef]

18. Tegen, I.; Lacis, A.A.; Fung, I. The influence on climate forcing of mineral aerosols from disturbed soils. Nature 1996, 380, 419-422. [CrossRef]

19. Tzanis, C.; Varotsos, C.A. Tropospheric aerosol forcing of climate: A case study for the greater area of Greece. Int. J. Remote Sens. 2008, 29, 2507-2517. [CrossRef]

20. Legrand, M.; Plana-Fattori, A.; N'Doume, C. Satellite detection of dust using the IR imagery of Meteosat: 1. Infrared difference dust index. J. Geophys. Res. 2001, 106, 18251-18274. [CrossRef]

21. Wendisch, M.; Hellmuth, O.; Ansmann, A.; Heintzenberg, J.; Engelmann, R.; Althausen, D.; Eichler, H.; Mueller, D.; Hu, M.; Zhang, Y.; et al. Radiative and dynamic effects of absorbing aerosol particles over the Pearl River Delta, China. Atmos. Environ. 2008, 42, 6405-6416. [CrossRef]

22. Babu, S.; Moorthy, K.; Manchanda, R.; Sinha, P.; Satheesh, S.; Vajja, D.; Srinivasan, S.; Kumar, V. Free tropospheric black carbon aerosol measurements using high altitude balloon: Do BC layers build 'their own homes' up in the atmosphere? Geophys. Res. Lett. 2011, 38, L08803. [CrossRef]

23. Johnson, B.; Shine, K.; Forster, P. The semi-direct aerosol effect: Impact of absorbing aerosols on marine stratocumulus. Q. J. R. Meteorol. Soc. 2004, 130, 1407-1422. [CrossRef]

24. Chen, S.; Huang, J.; Qian, Y.; Ge, J.; Su, J. Effects of aerosols on autumn precipitation over Mid-eastern China. J. Trop. Meteorol. 2014, 20, 242-250. [CrossRef]

25. Lin, L.; Gettelman, A.; Xu, Y.; Fu, Q. Simulated responses of terrestrial aridity to black carbon and sulfate aerosols. J. Geophys. Res. Atmos. 2016, 121, 785-794. [CrossRef]

26. Wang, Z.; Zhang, H.; Li, J.; Jing, X.; Lu, P. Radiative forcing and climate response due to the presence of black carbon in cloud droplets. J. Geophys. Res. Atmos. 2013, 118, 3662-3675. [CrossRef]

27. Chen, Y.; Peng, K.; Huang, J.; Kang, Y.; Zhang, H.; Jiang, X. Seasonal and regional variability of cloud liquid water path in northwestern China derived from MODIS/CERES observations. Int. J. Remote Sens. 2010, 31, 1037-1042. [CrossRef]

28. Zhang, H.; Wang, Z. Advances in Studies of Black Carbon Effects on Climate. Adv. Clim. Chang. Res. 2009, 5, 311-317. [CrossRef]

29. Wang, Z.; Zhang, H.; Shen, X. Radiative forcing and climate response due to black carbon in snow and ice. Adv. Atmos. Sci. 2011, 28, 1336-1344. [CrossRef]

30. Zhao, C.; Hu, Z.; Qian, Y.; Leung, L.R.; Huang, J.; Huang, M.; Jin, J.; Flanner, M.; Zhang, R.; Wang, H.; et al. Simulating black carbon and dust and their radiative forcing in seasonal snow: A case study over North China with field campaign measurements. Atmos. Chem. Phys. 2014, 14, 11475-11491. [CrossRef]

31. Krishnan, R.; Ramanathan, V. Evidence of surface cooling from absorbing aerosols. Geophys. Res. Lett. 2002, 29, 1340. [CrossRef]

32. Han, Z.; Li, J.; Xia, X.; Zhang, R. Investigation of direct radiative effects of aerosols in dust storm season over East Asia with an online coupled regional climate-chemistry-aerosol model. Atmos. Environ. 2012, 54, 688-699. [CrossRef]

33. Han, Z.; Li, J.; Guo, W.; Xiong, Z.; Zhang, W. A study of dust radiative feedback on dust cycle and meteorology over East Asia by a coupled regional climate-chemistry-aerosol model. Atmos. Environ. 2013, 68, 54-63. [CrossRef]

34. Cai, J.; Guan, Z.; Ma, F. Possible Combined Influences of Absorbing Aerosols and Anomalous Atmospheric Circulation on Summertime Diurnal Temperature Range Variation over the Middle and Lower Reaches of the Yangtze River. J. Meteorol. Res. 2016, 30, 927-943. [CrossRef]

35. Chen, S.; Huang, J.; Li, J.; Jia, R.; Jiang, N.; Kang, L.; Ma, X.; Xie, T. Comparison of dust emission, transport, and deposition between the Taklimakan Desert and Gobi Desert from 2007 to 2011. Sci. China Earth Sci. 2017, 60, 1-18. [CrossRef]

36. Zhang, H.; Wu, J. A study of radiative forcing and global warming potentials due to HFCs. Am. Inst. Phys. 2008. [CrossRef]

37. Zhang, H.; Ma, J.; Zheng, Y. Modeling study of the global distribution of radiative forcing by dust aerosol. Acta Meteorol. Sin. 2010, 24, 558-570. 
38. Prospero, J.M.; Ginoux, P.; Torres, O.; Nicholson, S.E.; Gill, T.E. Environmental characterization of global sources of atmospheric soil dust identified with the Nimbus 7 Total Ozone Mapping Spectrometer (TOMS) absorbing aerosol product. Rev. Geophys. 2002, 40. [CrossRef]

39. Dubovik, O.; Holben, B.; Eck, T.F.; Smirnov, A.; Kaufman, Y.J.; King, M.D.; Tang, D.; Slutsker, I. Variability of absorption and optical properties of key aerosol types observed in worldwide locations. J. Atmos. Sci. 2002, 59, 590-608. [CrossRef]

40. Lamarque, J.-F.; Bond, T.C.; Eyring, V.; Granier, C.; Heil, A.; Klimont, Z.; Lee, D.; Liousse, C.; Mieville, A.; Owen, B.; et al. Historical (1850-2000) gridded anthropogenic and biomass burning emissions of reactive gases and aerosols: Methodology and application. Atmos. Chem. Phys. 2010, 10, 7017-7039. [CrossRef]

41. Schaap, M.; Van Der Gon, H.A.C.; Dentener, F.J.; Visschedijk, A.J.H.; Van Loon, M.; Ten Brink, H.M.; Putaud, J.-P.; Guillaume, B.; Liousse, C.; Builtjes, P.J.H. Anthropogenic black carbon and fine aerosol distribution over Europe. J. Geophys. Res. Atmos. 2004, 109, D18. [CrossRef]

42. Tzanis, C.; Tsivola, E.; Efstathiou, M.; Varotsos, C. Forest fires pollution impact on the solar UV irradiance at the ground. Fresen. Environ. Bull. 2009, 18, 2151-2158.

43. Zhang, L.; Henze, D.; Grell, G.; Torres, O.; Jethva, H.; Lamsal, L. What factors control the trend of increasing AAOD over the United States in the last decade? J. Geophys. Res. Atmos. 2017, 122, 1797-1810. [CrossRef]

44. Kondo, Y.; Matsui, H.; Moteki, N.; Sahu, L.; Takegawa, N.; Kajino, M.; Zhao, Y.; Cubison, M.J.; Jimenez, J.L.; Vay, S.; et al. Emissions of black carbon, organic, and inorganic aerosols from biomass burning in North America and Asia in 2008. J. Geophys. Res. Atmos. 2011, 116, D8. [CrossRef]

45. Huang, J.; Fu, Q.; Zhang, W.; Wang, X.; Zhang, R.; Ye, H.; Warren, S.G. Dust and black carbon in seasonal snow across northern China. B Am. Meteorol. Soc. 2011, 92, 175-181. [CrossRef]

46. Lau, K.M.; Kim, K.M. Observational relationships between aerosol and Asian monsoon rainfall, and circulation. Geophy. Res. Lett. 2006, 33. [CrossRef]

47. Crutzen, P.J.; Andreae, M.O. Biomass burning in the tropics: Impact on atmospheric chemistry and biogeochemical cycles. Science 1990, 250, 1669-1678. [CrossRef] [PubMed]

48. Wang, C. Impact of direct radiative forcing of black carbon aerosols on tropical convective precipitation. Geophys. Res. Lett. 2007, 34. [CrossRef]

49. Clarke, A.D.; Noone, K.J. Soot in the Arctic snowpack: A cause for perturbations in radiative transfer. Atmos. Environ. 2007, 41, 64-72. [CrossRef]

50. Hegg, D.A.; Warren, S.G.; Grenfell, T.C.; Doherty, S.J.; Clarke, A.D. Sources of light-absorbing aerosol in arctic snow and their seasonal variation. Atmos. Chem. Phys. 2010, 10, 10923-10938. [CrossRef]

51. Huang, J.; Guan, X.; Ji, F. Enhanced cold-season warming in semi-arid regions. Atmos. Chem. Phys. 2012, 12, 5391-5398. [CrossRef]

52. Huang, J.; Yu, H.; Guan, X.; Wang, G.; Guo, R. Accelerated dryland expansion under climate change. Nat. Clim. Chang. 2016, 6, 166-171. [CrossRef]

53. Huang, J.; Yu, H.; Dai, A.; Wei, Y.; Kang, L. Drylands face potential threat under $2{ }^{\circ} \mathrm{C}$ global warming target. Nat. Clim. Chang. 2017, 7. [CrossRef]

54. Zhou, L.; Chen, H.; Dai, Y. Stronger warming amplification over drier ecoregions observed since 1979. Environ. Res. Lett. 2015, 10, 064012. [CrossRef]

55. Guan, X.; Huang, J.; Guo, R.; Yu, H.; Lin, P.; Zhang, Y. Role of radiatively forced temperature changes in enhanced semi-arid warming in the cold season over east Asia. Atmos. Chem. Phys. 2015, 15, 13777-13786. [CrossRef]

56. Ran, J.; Ji, M.; Huang, J.; Guan, X.; Qi, Y.; He, Y. Enhanced Cold-Season Warming in Arid and Semi-Arid Regions of China. Plateau Meteorol. 2014, 33, 947-956.

57. Huang, J.; Ji, M.; Xie, Y.; Wang, S.; He, Y.; Ran, J. Global semi-arid climate change over last 60 years. Clim. Dyn. 2016, 46, 1131-1150. [CrossRef]

58. He, Y.; Huang, J.; Ji, M. Impact of land-sea thermal contrast on interdecadal variation in circulation and blocking. Clim. Dyn. 2014, 43, 3267-3279. [CrossRef]

59. Zhou, L.; Chen, H.; Hua, W.; Dai, Y.; Wei, N. Mechanisms for stronger warming over drier ecoregions observed since 1979. Clim. Dyn. 2016, 47, 2955-2974. [CrossRef]

60. Zhang, Y.; Guan, X.; Yu, H.; Xie, Y.; Jin, H. Contributions of radiative factors to enhanced dryland warming over East Asia. Geophys. Res. Lett. 2017. [CrossRef] 
61. Lau, K.M.; Kim, M.K.; Kim, K.M. Asian summer monsoon anomalies induced by aerosol direct forcing: The role of the Tibetan Plateau. Clim. Dyn. 2006, 26, 855-864. [CrossRef]

62. Chen, S.; Huang, J.; Qian, Y.; Zhao, C.; Kang, L.; Yang, B.; Wang, Y.; Liu, Y.; Yuan, T.; Wang, T.; Ma, X.; Zhang, G. An Overview of Mineral Dust Modeling over East Asia. J. Meteorol. Res. 2017, 31, 633-653. [CrossRef]

63. Buchard, V.; da Silva, A.; Colarco, P.; Darmenov, A.; Randles, C.; Govindaraju, R.; Torres, O.; Campbell, J.; Spurr, R. Using the OMI aerosol index and absorption aerosol optical depth to evaluate the NASA MERRA Aerosol Reanalysis. Atmos. Chem. Phys. 2015, 15, 5743-5760. [CrossRef]

64. Peters, K.; Quaas, J.; Bellouin, N. Effects of absorbing aerosols in cloudy skies: A satellite study over the Atlantic Ocean. Atmos. Chem. Phys. 2011, 11, 1393-1404. [CrossRef]

65. Zhang, L.; Henze, D.; Grell, G.; Carmichael, G.; Bousserez, N.; Zhang, Q.; Torrres, O.; Ahn, C.; Lu, Z.; Cao, J.; et al. Constraining black carbon aerosol over Asia using OMI aerosol absorption optical depth and the adjoint of GEOS-Chem. Atmos. Chem. Phys. 2015, 15, 10281-10308. [CrossRef]

66. Torres, O.; Tanskanen, A.; Veihelmann, B.; Ahn, C.; Braak, R.; Bhartia, P.K.; Veefkind, P.; Levelt, P. Aerosols and surface UV products from Ozone Monitoring Instrument observations: An overview. J. Geophys. Res. Atmos. 2007, 112, D24. [CrossRef]

67. Torres, O.; Bhartia, P.K.; Sinyuk, A.; Welton, E.J.; Holben, B. Total Ozone Mapping Spectrometer measurements of aerosol absorption from space: Comparison to SAFARI 2000 ground-based observations. J. Geophys. Res. Atmos. 2005, 110, D10. [CrossRef]

68. Ahn, C.; Torres, O.; Jethva, H. Assessment of OMI near-UV aerosol optical depth over land. J. Geophys. Res. Atmos. 2014, 119, 2457-2473. [CrossRef]

69. Zhang, W.; Gu, X.; Xu, H.; Yu, T.; Zheng, F. Assessment of OMI near-UV aerosol optical depth over Central and East Asia. J. Geophys. Res. Atmos. 2016, 121, 382-398. [CrossRef]

70. Jethva, H.; Torres, O.; Ahn, C. Global assessment of OMI aerosol single-scattering albedo using ground-based AERONET inversion. J. Geophys. Res. Atmos. 2014, 119, 9020-9040. [CrossRef]

71. Levelt, P.; Hilsenrath, E.; Leppelmeier, G.; van den Oord, G.; Bhartia, P.; Tamminen, J.; de Haan, J.; Veefkind, J. Science objectives of the ozone monitoring instrument. IEEE Trans. Geomensci. Remote Sens. 2006, 44, 1199-1208. [CrossRef]

72. Chung, C.; Ramanathan, V.; Decremer, D. Observationally constrained estimates of carbonaceous aerosol radiative forcing. PANS 2012, 109, 11624-11629. [CrossRef] [PubMed]

73. OMI User's Guide. 2012. Available online: https://docserver.gesdisc.eosdis.nasa.gov/repository/Mission/ OMI/3.3_ScienceDataProductDocumentation/3.3.2_ProductRequirements_Designs/README.OMI_ DUG.pdf (accessed on 13 October 2017).

74. Crippa, M.; Janssens-Maenhout, G.; Dentener, F.; Guizzardi, D.; Sindelarova, K.; Muntean, M.; Van Dingenen, R.; Granier, C. Forty years of improvements in European air quality: Regional policy-industry interactions with global impacts. Atmos. Chem. Phys. 2016, 16, 3825-3841. [CrossRef]

75. Wang, X.; Huang, J.; Ji, M.; Higuchi, K. Variability of East Asia dust events and their long-term trend. Atmos. Environ. 2008, 42, 3156-3165. [CrossRef]

76. Kang, L.; Huang, J.; Chen, S.; Wang, X. Long-term trends of dust events over Tibetan Plateau during 1961-2010. Atmos. Environ. 2016, 125, 188-198. [CrossRef]

77. Yuan, T.; Chen, S.; Kang, L.; Chen, Z.; Luo, Y.; Zou, Q. Temporal and spatial distribution characteristics and change trends of dust intensity in dust source regions of China during 1961-2010. J. Arid Meteorol. 2016, 34, 927-935.

78. Wang, C.; Wang, X.; Liu, D.; Wu, H.; Lü, X.; Fang, Y.; Cheng, W.; Luo, W.; Jiang, P.; Shi, J.; et al. Aridity threshold in controlling ecosystem nitrogen cycling in arid and semi-arid grasslands. Nat. Commun. 2014, 5, 4799. [CrossRef] [PubMed]

79. Li, Y.; Huang, J.; Ji, M.; Ran, J. Dryland expansion in northern China from 1948 to 2008. Adv. Atmos. Sci. 2015, 32, 870-876. [CrossRef]

80. Lin, L.; Gettelman, A.; Fu, Q.; Xu, Y. Simulated differences in 21st century aridity due to different scenarios of greenhouse gases and aerosols. Clim. Chang. 2016, 1-16. [CrossRef]

81. Feng, S.; Fu, Q. Expansion of global drylands under a warming climate. Atmos. Chem. Phys. 2013, 13, 10081-10094. [CrossRef]

82. UNEP, N.M.; Thomas, D. World Atlas of Desertification; Edward Arnold: London, UK, 1992. 
83. Chen, M.; Xie, P.; Janowiak, J.; Arkin, P. Global Land Precipitation: A 50-year Monthly Analysis Based on Gauge Observations. J. Hydrometeorol. 2002, 3, 249-266. [CrossRef]

84. Qi, Y.; Ge, J.; Huang, J. Spatial and temporal distribution of MODIS and MISR aerosol optical depth over northern China and comparison with AERONET. Sci. Bull. 2013, 58, 2497-2506. [CrossRef]

85. Kim, S.W.; Yoon, S.C.; Kim, J.; Kim, S.Y. Seasonal and monthly variations of columnar aerosol optical properties over east Asia determined from multi-year MODIS, LIDAR, and AERONET Sun/sky radiometer measurements. Atmos. Environ. 2007, 41, 1634-1651. [CrossRef]

86. Kaskaoutis, D.G.; Kharol, S.K.; Sinha, P.R.; Singh, R.P.; Badarinath, K.V.S.; Mehdi, W.; Sharma, M. Contrasting aerosol trends over South Asia during the last decade based on MODIS observations. Atmos. Meas. Tech. Discuss. 2011, 4, 5275-5323. [CrossRef]

87. Cheng, T.; Chen, H.; Gu, X.; Yu, T.; Guo, J.; Guo, H. The inter-comparison of MODIS, MISR and GOCART aerosol products against AERONET data over China. J. Quant. Spectrosc. Radiat. Transf. 2012, 113, 2135-2145. [CrossRef]

88. Li, C.; Mao, J.; Lau, K.H.A.; Chen, J.C.; Yuan, Z.; Liu, X.; Zhu, A.; Liu, G. Characteristics of distribution and seasonal variation of aerosol optical depth in eastern China with MODIS products. Chin. Sci. Bull. 2003, 48, 2488-2495.

89. Xia, X.A.; Chen, H.B.; Wang, P.C.; Zong, X.M.; Qiu, J.H.; Philippe, G. Aerosol properties and their spatial and temporal variations over North China in spring 2001. Tellu B 2005, 57, 28-39.

90. Koike, M.; Moteki, N.; Khatri, P.; Takamura, T.; Takegawa, N.; Kondo, Y.; Hashioka, H.; Matsui, H.; Shimizu, A.; Sugimoto, N. Case study of absorption aerosol optical depth closure of black carbon over the East China Sea. J. Geophys. Res. Atmos. 2014, 119, 122-136. [CrossRef]

91. Hu, Z.; Zhao, C.; Huang, J.; Leung Ruby, L.; Qian, Y.; Yu, H.; Huang, L.; Kalashnikova, O. Trans-Pacific transport and evolution of aerosols: Evaluation of quasi-global WRF-Chem simulation with multiple observations. Geosci. Model Dev. 2016, 9, 1725-1746. [CrossRef]

92. Yang, M.; Howell, S.G.; Zhuang, J.; Huebert, B.J. Attribution of aerosol light absorption to black carbon, brown carbon, and dust in China-interpretations of atmospheric measurements during EAST-AIRE. Atmos. Chem. Phys. 2009, 9, 2035-2050. [CrossRef]

93. Wang, S.G.; Wang, J.Y.; Zhou, Z.J.; Shang, K.Z. Regional characteristics of three kinds of dust storm events in China. Atmos. Environ. 2005, 39, 509-520. [CrossRef]

94. Shao, Y.; Dong, C.H. A review on East Asian dust storm climate, modeling and moni-toring. Glob. Planet. Chang. 2006, 52, 1-22. [CrossRef]

95. Wu, J.; Fu, C. Simulation research of distribution transportation and radiative effects of black carbon aerosol in recent five spring seasons over East Asia region. Chin. J. Atmos. Sci. 2005, 29, 111-119.

96. Duncan, B.; Martin, R.; Staudt, A.; Yevich, R.; Logan, J. Interannual and seasonal variability of biomass burning emissions constrained by satellite observations. J. Geophys. Res. Atmos. 2003, 108, D2. [CrossRef]

97. Deng, X.; Tie, X.; Zhou, X.; Qu, D.; Zhong, L.; Tan, H.; Li, F.; Huang, X.; Bi, X.; Deng, T. Effects of Southeast Asia biomass burning on aerosols and ozone concentrations over the Pearl River Delta (PRD) region. Atmos. Environ. 2008, 42, 8493-8501. [CrossRef]

98. Babu, S.S.; Chaubey, J.P.; Krishna Moorthy, K.; Gogoi, M.M.; Kompalli, S.K.; Sreekanth, V.; Bagare, S.P.; Bhatt, B.C.; Gaur, V.K.; Prabhu, T.P.; et al. High altitude ( $4520 \mathrm{~m}$ amsl) measurements of black carbon aerosols over western trans-Himalayas: Seasonal heterogeneity and source apportionment. J. Geophys. Res. Atmos. 2011, 116, D24. [CrossRef]

99. Cao, J.; Lee, S.; Chow, J.; Watson, J.; Ho, K.; Zhang, R.; Jin, Z.; Shen, Z.; Chen, G.; Kang, Y.; et al. Spatial and seasonal distributions of carbonaceous aerosols over China. Atmos. Environ. 2007, 112, D22S11. [CrossRef]

100. Wang, S.; Xing, J.; Chatani, S.; Hao, J.; Klimont, Z.; Cofala, J.; Amann, M. Verification of anthropogenic emissions of China by satellite and ground observations. Atmos. Environ. 2011, 45, 6347-6358. [CrossRef]

101. Zhang, L.; Liao, H.; Li, J. Impacts of Asian summer monsoon on seasonal and interannual variations of aerosols over eastern China. J. Geophys. Res. Atmos. 2010, 115, D00K05. [CrossRef]

102. Streets, D.G.; Bond, T.C.; Carmichael, G.R.; Fernandes, S.D.; Fu, Q.; He, D.; Klimont, Z.; Nelson, S.M.; Tsai, N.Y.; Wang, M.Q.; et al. An inventory of gaseous and primary aerosol emissions in Asia in the year 2000. J. Geophys. Res. 2003, 108, 8809. [CrossRef]

103. Zhang, Q.; Streets, D.; Carmichael, G.; Hr, K.; Huo, H.; Kannari, A.; Klimont, Z.; Park, I.; Reddy, S.; Fu, J.; et al. Asian emissions in 2006 for the NASA INTEX-B mission. Atmos. Chem. Phys. 2009, 9, 5131-5153. [CrossRef] 
104. Gyawali, M.; Arnott, W.P.; Lewis, K.; Moosmüller, H. In situ aerosol optics in Reno, NV, USA during and after the summer 2008 California wildfires and the influence of absorbing and non-absorbing organic coatings on spectral light absorption. Atmos. Chem. Phys. 2009, 9, 8007-8015. [CrossRef]

105. Ialongo, I.; Buchard, V.; Brogniez, C.; Casale, G.; Siani, A. Aerosol Single Scattering Albedo retrieval in the UV range: An application to OMI satellite validation. Atmos. Chem. Phys. 2010, 10, 331-340. [CrossRef]

106. Hansen, J.; Sato, M.; Ruedy, R. Radiative forcing and climate response. J. Geophys. Res. 1997, 102, 6831-6864. [CrossRef]

107. Liu, Y.; Huang, J.; Shi, G.; Takamura, T.; Khatri, P.; Bi, J.; Shi, J.; Wang, T.; Wang, X.; Zhang, B. Aerosol optical properties and radiative effect determined from sky-radiometer over Loess Plateau of Northwest China. Atmos. Chem. Phys. 2011, 11, 11455-11463. [CrossRef]

108. Qiu, J.; Yang, J. Absorption properties of urban/suburban aerosols in China. Adv. Atmos. Sci. 2008, 25, 1-10. [CrossRef]

109. Streets, D.; Yu, C.; Wu, Y.; Chin, M.; Zhao, Z.; Hayasakae, T.; Shi, G. Aerosol trends over China, 1980-2000. Atmos. Res. 2008, 88, 174-182. [CrossRef]

110. De Meij, A.; Pozzer, A.; Lelieveld, J. Trend analysis in aerosol optical depths and pollutant emission estimates between 2000 and 2009. Atmos. Environ. 2012, 51, 75-85. [CrossRef]

111. Lu, Z.; Streets, D.; Zhang, Q.; Wang, S.; Carmichael, G.; Cheng, Y.; Wei, C.; Chin, M.; Diehl, T.; Tan, Q. Sulfur dioxide emissions in China and sulfur trends in East Asia since 2000. Atmos. Chem. Phys. 2010, 10, 6311-6331. [CrossRef]

112. Bond, T.; Streets, D.; Yarber, K.; Nelson, S.; Woo, J.; Klimint, Z. A technology-based global inventory of black and organic carbon emissions from combustion. J. Geophys. Res. 2004, 109, D14203. [CrossRef]

113. Mallet, M.; Dubovik, O.; Nabat, P.; Dulac, F.; Kahn, R.; Sciare, J.; Paronis, D.; Léon, J.F. Absorption properties of Mediterranean aerosols obtained from multi-year ground-based remote sensing observations. Atmos. Chem. Phys. 2013, 13, 9195-9210. [CrossRef]

(C) 2017 by the authors. Licensee MDPI, Basel, Switzerland. This article is an open access article distributed under the terms and conditions of the Creative Commons Attribution (CC BY) license (http:// creativecommons.org/licenses/by/4.0/). 